\title{
Integrating Hydrogen in Single-Price Electricity Systems: The Effects of Spatial Economic Signals
}

\author{
Frederik vom Scheidt ${ }^{a, *}$, Jingyi $\mathbf{Q u}^{b}$, Philipp Staudt ${ }^{a}$, Dharik S. Mallapragada ${ }^{c}$ and \\ Christof Weinhardt ${ }^{a}$ \\ ${ }^{a}$ Karlsruhe Institute of Technology, Karlsruhe, Germany \\ ${ }^{b}$ FZI Research Center for Information Technology, Karlsruhe, Germany \\ ${ }^{c}$ Massachusetts Institute of Technology, Cambridge, USA
}

\section{ARTICLE INFO}

\section{Keywords:}

Hydrogen

Electricity markets

Nodal pricing

Congestion management

Sector coupling

Power-to-Gas

Electrolysis

\begin{abstract}
A B S T R ACT
Hydrogen can contribute substantially to the reduction of carbon emissions in industry and transportation. However, the production of hydrogen through electrolysis creates interdependencies between hydrogen supply chains and electricity systems. Therefore, as governments worldwide are planning considerable financial subsidies and new regulation to promote hydrogen infrastructure investments in the next years, energy policy research is needed to guide such policies with holistic analyses. In this study, we link a electrolytic hydrogen supply chain model with an electricity system dispatch model. We use this methodology for a cross-sectoral case study of Germany in 2030. We find that hydrogen infrastructure investments and their effects on the electricity system are strongly influenced by electricity prices. Given current uniform zonal prices, hydrogen production increases congestion costs in the electricity grid by $11 \%$. In contrast, passing spatially resolved electricity price signals leads to electrolyzers being placed at low-cost grid nodes and further away from consumption centers. This causes lower end-use costs for hydrogen. Moreover, congestion management costs decrease substantially, by $24 \%$ compared to the benchmark case without hydrogen. These savings could be transferred into according subsidies for hydrogen production. Thus, our study demonstrates the benefits of differentiating subsidies for hydrogen production based on spatial criteria.
\end{abstract}

\section{Introduction}

Hydrogen produced from low-carbon sources can contribute substantially to mitigating emissions in sectors that are difficult or impossible to electrify directly. Governments worldwide, and in particular in Europe, have announced strategies and billions of public funding to develop large-scale hydrogen infrastructure, that is centered on electrolytic hydrogen supply (Hydrogen Council and McKinsey \& Company, 2021). Since hydrogen production from electrolysis uses large amounts of electricity, a future hydrogen sector will introduce new interdependencies with the electricity sector. While electricity prices influence the cost-minimal installation (vom Scheidt et al., 2021) and operation (Guerra et al., 2019) of electrolyzers, these electrolyzers in turn introduce new electricity demand into the bulk power system, influencing in the short term the usage of renewable energy (Ruhnau, 2020; Bødal et al., 2020), as well as congestion of power networks (vom Scheidt et al., 2021; Xiong et al., 2021), and in the long term the need for electricity generation and transmission capacity (Bødal et al., 2020). Most importantly, the effects of these interdependencies will be strong and will prevail for a long time, because electrolyzers are large-scale, stationary consumers with typical lifetimes of ten years and more (Schmidt et al., 2017).

The integration of electrolyzers in European grids raises

\footnotetext{
${ }^{*}$ Corresponding author

frederik.scheidt@it.edu (F.v. Scheidt)

frederik.scheidtekit.edu (F.v. Scheidt)

ORCID(s): 0000-0001-6493-5073
}

some unique questions as European wholesale power markets are designed as single-price zonal markets that overlook intra-zonal transmission capacities and price variations. Such single-price zonal market designs are already leading to rising congestion management costs in many electricity systems (Staudt et al., 2017). In Germany, the costs for congestion management have risen to almost a billion Euro annually, and especially the curtailment of renewable energy plants is increasing (Xiong et al., 2021). Without appropriate policy to guide system-beneficial integration, hydrogen production might strongly aggravate these effects. While the importance of market cost-reflective price-regulation and subsidization of electrolyzers has been voiced in the political sphere (European Commission, 2020), there is a prevailing lack of energy policy research to guide efficient integration of hydrogen infrastructure into the electricity sector.

Therefore, in this study, we link an electrolytic hydrogen supply chain model with an electricity system dispatch model to analyze the cost-minimal hydrogen infrastructure setup in electricity markets using zonal vs. nodal pricing structure, using Germany 2030 as a case study. We find that under current regulation with uniform electricity prices, the cost-minimal solution is to produce hydrogen close to locations of consumption as one would expect. These locations partly coincide with high locational marginal electricity costs. Consequently, hydrogen production aggravates the inefficiencies of single-price markets and increases congestion management costs substantially.

We compare this benchmark scenario to a case in which 
electrolyzers are offered spatially differentiated (nodal) price signals based on the locational marginal prices that would form in a nodal pricing system. We find that such nodal signals lead to lower costs for hydrogen, higher shares of hydrogen production at low-price nodes, and longer transport distances. This demonstrates the sensitivity of hydrogen supply chains to spatial prices or subsidies. Moreover, in this scenario, the integration of hydrogen leads to congestion management costs that are substantially lower than in the benchmark scenario and even below a scenario without hydrogen. Interestingly, these avoided redispatch costs could already cover most of the subsidies a regulator would have to pay to mimic nodal prices for hydrogen within the existing single-price market design.

Thus, in a time in which many policy makers and regulators in single-price markets are planning future hydrogen supply systems and corresponding subsidies for hydrogen infrastructure, our study highlights the considerable benefits of differentiating those subsidies with respect to spatial criteria.

\section{Background}

Several past studies have addressed the spatial aspects of hydrogen supply chains that use grid electricity for hydrogen production. Robinius et al. (2017); Reuß et al. (2019); Emonts et al. (2019) present models that link a hydrogen supply chain with a national electricity grid. Their studies provide a high spatial granularity, i.e. the third level of the Nomenclature of Territorial Units for Statistics (NUTS-3) (European parliament and European council, 2003). The authors apply their model to the case of hydrogen fueled passenger cars in Germany in 2050 and identify favorable regions for hydrogen production in Germany. Runge et al. (2019) optimize supply chains for synthetic fuels, including hydrogen stored in liquid organic hydrogen carrier (LOHC) material. Besides considering uniform single-prices, the authors also present a case in which they calculate state-level representative nodal prices for two exemplary states in Germany (NUTS-2 level) and allow transportation of hydrogen between the two states. This causes increased hydrogen production in the state with lower prices. The authors acknowledge the importance of future work analyzing feedback effects on the electricity system. We fill their identified gap with this study.

Zhang et al. (2020) analyze the flexible operation of electrolyzers that produce hydrogen for light, medium- and heavyduty fuel cell electric vehicles (FCEVs) in the Western United States of America. They find evidence that increasing electrolyzer flexibility lowers hydrogen and electricity generation cost and $\mathrm{CO}_{2}$ emissions. With a similar focus on temporal aspects, it has been demonstrated that flexibility of electrolytic hydrogen production enables more renewable integration for case studies in Texas, USA (Bødal et al., 2020) and Germany (Ruhnau, 2020).

Rose and Neumann (2020a) focus on hydrogen supply for heavy-duty trucks from on-site electrolysis at highway fuel stations. They jointly optimize the infrastructure of fuel stations and the electricity system. They find that using $100 \%$ hydrogen fueled heavy-duty trucks in Germany in 2050 would increase the total electricity demand by about $60 \mathrm{TWh}$ and cause additional infrastructure costs of about 12 billion euro per year. They note that nodal prices contain important information about "cost-effective energy consumption from a system perspective" and that investors in hydrogen infrastructure should consider the system perspective. This idea is expanded and implemented by vom Scheidt et al. (2021). The authors link a hydrogen supply chain optimization model and a nodal electricity system dispatch model and observe their interdependence in an initial case study of hydrogenfueled trucks and passenger cars. They find that compared to current uniform single-price prices, nodal prices would lead to more hydrogen generation at low-price nodes. This in turn causes substantially lower congestion management costs. However, their analysis, like all previous ones, focuses on a small subset of hydrogen demand, i.e. demand from the transport sector.

Xiong et al. (2021) provide another perspective on the topic of hydrogen integration in single-price markets. They do not consider the effects of hydrogen production on dayahead energy wholesale markets, but analyze how Powerto-Gas plants (i.e. electrolyzers) can serve as a redispatch option. They find that curtailment of renewable generation can be reduced by $12 \%$ when electrolyzers are installed for performing redispatch at a few frequently curtailed nodes in the German grid of 2015. The study thus showcases the importance of spatial consideration in hydrogen infrastructure planning. However, the study disregards spatial aspects of the hydrogen supply chain and disregards how policy makers could incentivize investors to build electrolyzers at the identified nodes. Moreover, the direct political applicability of the study is restricted, because future hydrogen volumes, shares of renewable and conventional generation, and spatial distribution of generation will be much different than in the used scenario from 2015.

In summary, past research indicates that the spatial dimension of hydrogen integration matters. Within the limitations of single sector analyses and/or a reduced network consideration, studies have demonstrated that electrolyzer locations influence grid congestion. However, to the best of our knowledge, no past study has evaluated the cost-optimal hydrogen supply chain for electrolytic hydrogen use for a broad range of hydrogen demand sectors, namely steel, ammonia, methanol, refineries, and transportation, considered the effect of alternative electricity price signals, and assessed the feedback effects of the resulting supply chains. Such analysis is timely from a policy perspective given the prospect of significant electrolyzer capacity integration over the next decade in the German power grid. Therefore, we pose the following research questions to guide future policy decision on hydrogen subsidization:

1. What is the cost-minimal supply chain design using electrolytic hydrogen production for the combined hydrogen demand from all major relevant sectors in 2030 


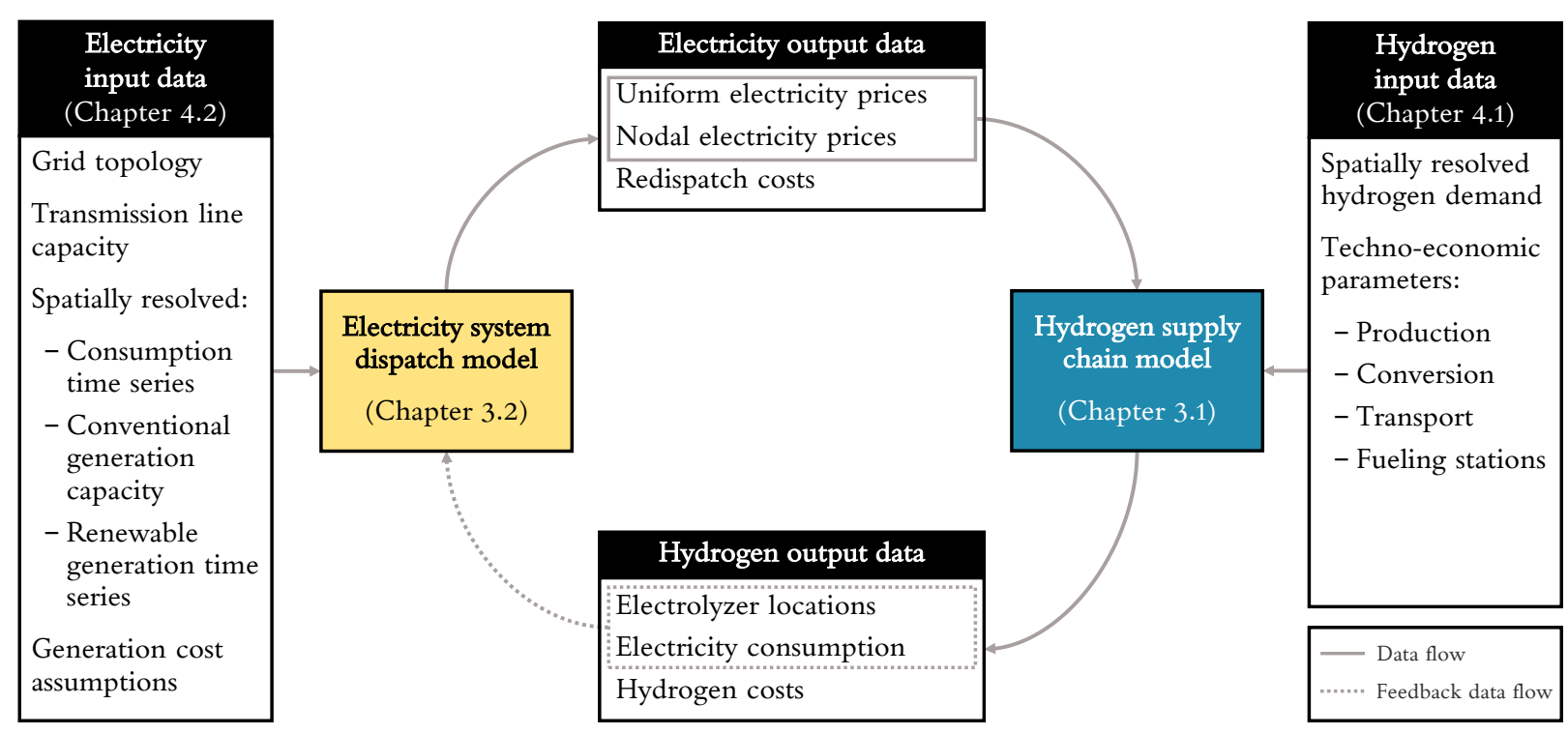

Figure 1: Methodology: Modelling the hydrogen and electricity system and linking them through inputs and outputs

in Germany?

2. How do electricity price signals (single-price versus nodal) influence the cost-minimal locations of electrolyzers and the costs of hydrogen?

3. How does hydrogen production change electricity wholesale prices and congestion management costs under single-price and nodal price signals?

\section{Methodology}

To address the research questions, we model the hydrogen supply chain and the electricity system and link both models through their respective inputs and outputs. As shown in 1, we proceed in three steps. First, we parametrize an electricity system dispatch model without hydrogen and compute uniform prices, nodal prices, and redispatch costs. Second, utilizing the computed electricity prices, we run the hydrogen model to identify the cost-minimal spatial siting of electrolyzers, their capacities, and the hydrogen transportation. We calculate one scenario for uniform prices to reflect current regulation and one scenario for nodal prices, to reflect a more efficient solution. Third, we feed back the resulting locations and capacities of the electrolyzers as additional regional loads into the electricity model. We calculate consequential changes in wholesale electricity prices and congestion management costs. Both models are implemented in Python 3.7.3, and solved using the Gurobi solver 8.1.1.

\subsection{Hydrogen supply chain model}

In the following, we describe the details of the hydrogen supply chain model. It represents an enhanced version of the model in (vom Scheidt et al., 2021). Due to the temporal uncertainty in demand from end-use sectors the model assumes time-invariant hydrogen consumption.

\subsubsection{Objective function}

The model minimizes the total end-use costs of hydrogen, which consist of capital costs and operating costs for electrolytic production $(P C C, P O C)$, conversion $(C C C$, $C O C$ ) and transportation (TCC,TOC) of hydrogen, and the fueling stations $(S C C, S O C)$ (1). There are four decision variables. (i) $X_{p}$ is a binary variable that indicates whether an electrolyzer is installed at a location $p$ (1) or not (0). (ii) $H P_{p} \in[0, \infty)$ denotes the amount of hydrogen produced at $p$ in $k g_{H_{2}}$ per day. (iii) $Y_{p, c}$ is binary and indicates whether hydrogen is transported from a production location $p$ to a consumption location $c$ (1) or not (0). (iv) $H T_{p, c} \in[0, \infty)$ denotes the amount of hydrogen transported from $p$ to $c$ in $k g_{H_{2}}$ per day. $P$ and $C$ represent the set of all potential electrolyzer plant locations $p$, and consumption locations $c$, respectively. Thus, the model outputs the cost-minimal locations of electrolyzers, their individual daily production, the transportation volume between each electrolyzer and point of consumption, and the resulting end-use costs of hydrogen.

The model can be parametrized for three possible hydrogen states $s$ for transportation via delivery trailers: liquefied (LH2), and bound in LOHC. These three states require different technologies for conversion, transportation and fueling stations and thus cause different costs. The annotation of decision variables, indices and input variables is provided in Table 1. 
Table 1

Notation for hydrogen model - Decision variables, indices and variables

\begin{tabular}{|c|c|}
\hline \multicolumn{2}{|c|}{ Decision variables } \\
\hline$X_{p} \in\{0,1\}$ & $\begin{array}{l}\text { Hydrogen production/import at location } \\
\mathrm{p}(1) \text {, or not }(0)\end{array}$ \\
\hline$H P_{p} \in[0, \infty)$ & $\begin{array}{l}\text { Daily amount of hydrogen production at } \\
\mathrm{p}\left[\mathrm{kg}_{\mathrm{H}_{2}} / \text { day }\right]\end{array}$ \\
\hline$Y_{p, c} \in\{0,1\}$ & $\begin{array}{l}\text { Hydrogen transport from } \mathrm{p} \text { to } \mathrm{c}(1) \text {, or } \\
\text { not }(0)\end{array}$ \\
\hline$H T_{p, c} \in[0, \infty)$ & $\begin{array}{l}\text { Daily amount of hydrogen transportation } \\
\text { from } \mathrm{p} \text { to } \mathrm{c}\left[\mathrm{kg}_{\mathrm{H}_{2}} / \mathrm{day}\right]\end{array}$ \\
\hline \multicolumn{2}{|l|}{ Indices } \\
\hline$C$ & Set of consumption locations \\
\hline$P_{\text {Production }}$ & $\begin{array}{l}\text { Set of domestic hydrogen production } \\
\text { locations }\end{array}$ \\
\hline$P_{\text {Import }}$ & Set of hydrogen import locations \\
\hline$S$ & $\begin{array}{l}\text { Set of hydrogen transportation states } \\
\{\mathrm{GH} 2, \mathrm{LH} 2, \mathrm{LOHC}\}\end{array}$ \\
\hline \multicolumn{2}{|l|}{ Input variables } \\
\hline$P C C_{p}$ & Production capital cost at $p$ [EUR] \\
\hline$C C C_{p, s}^{p}$ & Conversion capital cost of $s$ at $p$ [EUR] \\
\hline$T C C_{s}$ & Transportation capital cost of $s$ [EUR] \\
\hline$S C C_{s}$ & $\begin{array}{l}\text { Total fueling station capital cost of } s \\
\text { [EUR] }\end{array}$ \\
\hline $\mathrm{POC}_{p}$ & Production operating cost at $p$ [EUR] \\
\hline$C O C_{p, s}^{p}$ & $\begin{array}{l}\text { Conversion operating cost of } s \text { at } p \\
\text { [EUR] }\end{array}$ \\
\hline$T O C_{p, c, s}$ & $\begin{array}{l}\text { Transportation operating cost of } s \text { from } \\
p \text { to } c \text { [EUR] }\end{array}$ \\
\hline $\mathrm{SOC}_{\mathrm{s}}$ & $\begin{array}{l}\text { Total fueling station operating cost of } s \\
\text { [EUR] }\end{array}$ \\
\hline
\end{tabular}

The four components of capital costs include specific annual operation and management costs $(O \& M)$ and annuity factors $(A F)$. The annuity factors account for the depreciation of one-time investments over multiple years and depend on the weighted average cost of capital (WACC [\%]) and depreciation periods ( $a$ [years] (2). Equations 3 to 7 and the notations in Table 2 provide details on the capital cost components. Notably, the model includes overseas imports of hydrogen. Imports do not incur any capital costs for production and conversion (4), but specific production operating costs (9). Moreover, conversion capital costs are assumed to occur in bulk and independently of the location (5). Details for operating costs are provided in Equations 8 to 17. They include operating costs for domestic production (8) and import (9) of hydrogen. Furthermore, they include the costs of converting hydrogen. In the case of gaseous delivery, hydrogen is compressed (10). For liquid delivery, hydrogen needs to be liquefied and later evaporated at the location of consumption (11). For LOHC delivery, the carrier material needs to be hydrogenated and later dehydrogenated at the location of consumption (12). For LH2 and LOHC, we assume that imports already arrive in the respective form and thus do not require the first conversion step for domestic delivery.
Table 2

Notation for hydrogen model - input parameters

\begin{tabular}{|c|c|}
\hline$a$ & Depreciation period [years] \\
\hline$A F$ & Annuity factor $[\%]$ \\
\hline$C A P_{\text {Import }}$ & Import capacity $\left[\mathrm{kg}_{\mathrm{H}_{2}} /\right.$ day $]$ \\
\hline$C A P_{\text {Production,max }}$ & Maximum production capacity $\left[\mathrm{kg}_{\mathrm{H}_{2}} /\right.$ day $]$ \\
\hline$C A P_{\text {Production,min }}$ & Minimum production capacity $\left[\mathrm{kg}_{\mathrm{H}_{2}} /\right.$ day] \\
\hline$C A P_{\text {Trailer }_{s}}$ & $\begin{array}{l}\text { Capacity of delivery trailer for state } s \\
{\left[\mathrm{~kg}_{\mathrm{H}_{2}}\right]}\end{array}$ \\
\hline$D I S T_{p, c}$ & Air-line distance between $\mathrm{p}$ and $\mathrm{c}[\mathrm{km}]$ \\
\hline$D F$ & Detour factor [-] \\
\hline$D S$ & Driving speed $[\mathrm{km} / \mathrm{h}]$ \\
\hline$D U R_{\text {Driving }_{s}}$ & Duration of driving time $[\mathrm{h}]$ \\
\hline$D U R_{\text {Loading }_{s}}$ & Duration of loading and unloading [h] \\
\hline$E C$ & Electricity consumption $\left[k W h_{e l} / k g_{H_{2}}\right]$ \\
\hline$E D$ & Energy density of hydrogen $\left[\mathrm{kWh} h_{\mathrm{H}_{2}} / \mathrm{kg}_{\mathrm{H}_{2}}\right]$ \\
\hline$E E$ & Electric efficiency $\left[k W h_{\mathrm{H}_{2}} / k W h_{e l}\right]$ \\
\hline EP & $\begin{array}{l}\text { Uniform single electricity price } \\
\text { [EUR/kWhel }]\end{array}$ \\
\hline$E P_{p}$ & Electricity price at $\mathrm{p}\left[\mathrm{EUR} / k W h_{e l}\right]$ \\
\hline$F C_{\text {Truck }}$ & Fuel consumption of delivery truck $[\mathrm{l} / \mathrm{km}]$ \\
\hline$F L H_{\text {Electrolyzer }}$ & Full load hours of electrolyzers [h] \\
\hline FP & Fuel price [EUR/liter] \\
\hline$N G C_{\text {Station }_{s}}$ & $\begin{array}{l}\text { Natural gas consumption of fuel station of } \\
\text { hydrogen state } \mathrm{s}\left[\mathrm{kW} h_{\mathrm{NG}} / \mathrm{kg}_{\mathrm{H}_{2}}\right]\end{array}$ \\
\hline$H D_{c}$ & $\begin{array}{l}\text { Daily hydrogen demand at location c } \\
{\left[\mathrm{kg}_{\mathrm{H}_{2}} / \text { day }\right]}\end{array}$ \\
\hline$H I C$ & Hydrogen import costs [EUR/ $\left.\mathrm{kg}_{\mathrm{H}_{2}}\right]$ \\
\hline$I C_{\text {Conversion }_{s}}$ & $\begin{array}{l}\text { Capacity-specific investment costs of } \\
\text { conversion equipment [EUR/ } \mathrm{kg}_{\mathrm{H}_{2}} \text { ] }\end{array}$ \\
\hline$I C_{\text {Electrolyzer }}$ & $\begin{array}{l}\text { Capacity-dependent investment costs of } \\
\text { electrolyzer }\left[\text { EUR } / k W_{e l}\right]\end{array}$ \\
\hline$I C_{\text {Station }_{s}}$ & $\begin{array}{l}\text { Investment cost per fuel station for state s } \\
\text { [EUR] }\end{array}$ \\
\hline$I C_{\text {Trailers }_{s}}$ & $\begin{array}{l}\text { Investment cost per trailer for state s } \\
\text { [EUR] }\end{array}$ \\
\hline$I C_{T r u}$ & Investment cost per truck [EUR] \\
\hline$M$ & A very large positive number [-] \\
\hline$N S$ & Number of fuel stations [-] \\
\hline$N G P$ & Natural gas price $\left[\right.$ EUR $\left./ k W h_{N G}\right]$ \\
\hline$N T_{s}$ & Number of trucks for product state s [-] \\
\hline$N T_{\text {Trailers }_{s}}$ & Number of trailers for product state s [-] \\
\hline$O \& M$ & $\begin{array}{l}\text { Operation and maintenance cost factor } \\
{[\%]}\end{array}$ \\
\hline$T$ & Toll cost $[\mathrm{EUR} / \mathrm{km}]$ \\
\hline$W$ & Wage [EUR/hour] \\
\hline$W A C C$ & Weighted average cost of capital [\%] \\
\hline
\end{tabular}

After initial conversion, hydrogen is transported to the consumption sinks. Hydrogen can be transported via tube trailers mounted onto delivery trucks, or via pipelines. Since related work indicates that transport via pipelines only becomes economically viable for high demand scenarios and long transport distances (Reuß et al., 2019; Robinius et al., 2017), our model focuses on transport via tube trailers on delivery trucks. ${ }^{1}$ Thus, transport operating costs consist of

\footnotetext{
${ }^{1}$ As hydrogen volumes grow, transport via dedicated hydrogen pipelines could gain relevance. Future work could expand our model by offering both truck based and pipeline based hydrogen transportation.
} 
costs for labor, fuel, and toll (13). Labor costs depend on the time that drivers spend loading, driving, and unloading the delivery trailers (14). A fixed loading and unloading time per delivery is assumed. Round-trip driving time is determined by the distance between connected production plants and points of consumption, as well as the driving speed $D S$. Transport distances are approximated via air-line distance, multiplied with a detour factor of 1.3 , in line with Reuß (2019). Since the daily capacity of fueling stations is assumed to be smaller than the capacity of one delivery trailer, we multiply the distances to fueling stations with a frequency factor $H D_{c} / C A P_{\text {Trailer }_{s}}$ (15) simulating that they are not provided with hydrogen on a daily basis. This also applies to fuel and toll costs (16).

$$
\begin{array}{r}
\min _{X_{p}, H P_{p}, Y_{p, c}}\left(\sum_{p \in P} P C C_{p}+\sum_{p \in P} C C C_{p, s}+T C C_{s}+S C C_{s}\right. \\
+\sum_{p \in P} P O C_{p, s}\left(\boldsymbol{X}_{p}, \boldsymbol{H} \boldsymbol{P}_{p}\right)+\sum_{p \in P} C O C_{p, s}\left(\boldsymbol{X}_{p}, \boldsymbol{H} \boldsymbol{P}_{p}\right) \\
\left.+\sum_{p \in P} \sum_{c \in C} T O C_{p, c, s}\left(\boldsymbol{Y}_{p, c}, \boldsymbol{H} T_{p, c}\right)+S O C_{s}\right) \\
A F=\frac{(1+W A C C)^{a} * W A C C}{(1+W A C C)^{a}-1}
\end{array}
$$

$$
\begin{array}{r}
P C C_{p}=X_{p} * \frac{H P_{p} * E D * I C_{\text {Electrolyzer }}}{F L H * E E} \\
*\left(1+O \& M_{\text {Electrolyzer }}\right) \\
* A F_{\text {Electrolyzer }} \quad \forall p \in P_{\text {Production }}
\end{array}
$$

$$
P C C_{\text {Import }}=0
$$

$$
\begin{array}{r}
C C C_{s}=I C_{\text {Conversion }_{s}} *\left(1+O \& M_{\text {Conversion }_{s}}\right) \\
* A F_{\text {Conversion }_{s}} \quad \forall s \in S
\end{array}
$$

$$
\begin{array}{r}
T C C_{S}=I C_{\text {Trucks }} * N T_{s} *\left(1+O \& M_{\text {Trucks }}\right) \\
* A F_{\text {Trucks }}+I C_{\text {Trailers }_{s}} * N T_{S} \\
*\left(1+O \& M_{\text {Trailers }_{s}}\right) * A F_{\text {Trailers }} \quad \forall s \in S
\end{array}
$$$$
S C C_{S}=I C_{\text {Station }_{s}} * N S *\left(1+O \& M_{\text {Station }}\right)
$$

$$
A F_{\text {Station }} \forall s \in S
$$

$$
\begin{array}{r}
P O C_{p}=H P_{p} * E C_{\text {Production }} * E P_{p} * 365 \\
\forall p \in P_{\text {Production }}
\end{array}
$$

$$
P O C_{\text {Import }}=H P_{\text {Import }} * H I C * 365
$$

$$
\begin{aligned}
& C O C_{p, G H 2}=\sum_{p \in P_{\text {Production }}} H P_{p} * E C_{\text {Compression }} \\
& * E P_{p} *\left(1+\text { Loss }_{\text {Compression }}\right) * 365 \\
& C O C_{p, L H 2}=\left(\sum_{p \in P_{\text {Production }}} H P_{p} * E C_{\text {Liquefaction }}\right. \\
& \left.* E P_{p} *\left(1+\text { Loss }_{\text {Lique faction }}\right)\right) \\
& +\left(\sum_{p \in P} H P_{p} * E C_{\text {Evaporation }} * E P\right. \\
& \left.*\left(1+\operatorname{Loss}_{\text {Evaporation }}\right)\right) * 365 \\
& C O C_{p, L O H C}=\left(\sum_{p \in P \backslash \text { Import }} H P_{p} * E C_{H y d \text { rogenation }}\right. \\
& \left.* E P_{p} *\left(1+\text { Loss }_{\text {Hydrogenation }}\right)\right) \\
& +\left(\sum _ { p \in P } H P _ { p } * \left(E P * E C_{\text {Dehydrogenation }}\right.\right. \\
& \left.+N G P * N G C_{\text {Dehydrogenation }}\right) \\
& \left.*\left(1+\text { Loss }_{\text {Dehydrogenation }}\right)\right) * 365
\end{aligned}
$$

$$
\text { TOC }_{s}=\text { LaborCosts }+ \text { Fuel AndTollCosts }
$$

$$
\text { LaborCosts }=\left(D U R_{\text {Driving }_{s}}+D U R_{\text {Loading }_{s}} * N T_{s}\right)
$$$$
* W
$$

$$
\begin{array}{r}
\text { DrivingTime }_{S}=\left(\sum_{p \in P} \sum_{c \in C_{\text {Industry }}} Y_{p, c} * D I S T p, c\right. \\
\left.+\sum_{p \in P} \sum_{c \in C_{\text {Stations }}} Y_{p, c} * D I S T_{p, c} * \frac{H D_{c}}{C A P_{\text {Trailer }_{s}}}\right) \\
* \frac{2 * D F}{D S}
\end{array}
$$

$$
\begin{array}{r}
\text { Fuel AndTollCosts }=\left(F C_{\text {Truck }} * F P+T\right) * 2 \\
* D F *\left(\left(\sum_{p \in P} \sum_{c \in C_{\text {Industry }}} Y_{p, c} * D I S T p, c\right)\right. \\
\left.+\left(\sum_{p \in P} \sum_{c \in C_{\text {Stations }}} Y_{p, c} * D I S T_{p, c} * \frac{H D_{c}}{C A P_{\text {Trailer }}}\right)\right)
\end{array}
$$

$$
\begin{aligned}
S_{S O C_{S}}= & \left(E_{\text {Station }_{s}} * E P+N G C_{\text {Station }_{s}} * N G P\right) \\
& *\left(1+\text { Loss }_{\text {Station }_{s}}\right) * \sum_{c \in C_{\text {Stations }}} H D_{c} * 365
\end{aligned}
$$

\subsubsection{Constraints}

The model includes both domestic production and an exogenously given import at one fixed node. The sum of daily 
domestic and imported hydrogen production $H P$ must satisfy the sum of the exogenously given demand $H D$ (18). Hydrogen output $H P_{p}$ of each electrolyzer depends on its installed capacity, which varies between a fixed minimum (19) and maximum (20) value. The import nodes and their capacity are exogenously set $(21,22)$. In sum, the daily amount of hydrogen transported from an electrolyzer must not exceed its production (23). The daily amount transported to a consumer must meet its demand (24). Positive transport volume from a plant to a consumption location is only possible if the delivery connection is established via binary variable $Y$ (25). Thus, one limitation of the model is that it does not consider short term or long term temporal variations in hydrogen transportation or consumption and thus neglects storage. While out of scope of this study, future work could attempt to identify short term and long term temporal patterns of hydrogen demand from industry and transportation. ${ }^{2} \mathrm{We}$ do assess a sensitivity case "FlexOp" in which transportation and consumption remain continuous, but the production is temporally flexible. This allows us to identify an optimistic estimate of the potential cost savings that flexible electrolyzer operation can yield.

$$
\begin{gathered}
\sum_{p \in P} H P_{p}=\sum_{c \in C} H D_{c} \\
H P_{p} \geq C A P_{\text {Production,min }} * X_{p} \\
\forall p \in P_{\text {Production }} \\
H P_{p} \leq C A P_{\text {Production,max }} * X_{p} \\
\forall p \in P_{\text {Production }} \\
\quad \forall p \in P_{\text {Import }} \\
X_{p}=1 \quad \forall p \in P_{I m p o r t} \\
H P_{p}=C A P_{I m p o r t} * X_{p} \quad \forall p \\
\sum_{c \in C}^{H} T_{p, c} \leq H P_{p} \quad \forall p \in P \\
\sum_{p \in P} H T_{p, c} \geq H D_{c} \quad \forall c \in C
\end{gathered}
$$

$$
H T_{p, c, s} \leq Y_{p, c} * M \quad \forall c \in C, \forall p \in P
$$

${ }^{2}$ Regarding long term storage, techno-economic parameters are presented by Reuß et al. (2019) and locations with high geological potential for hydrogen storage are presented by Caglayan et al. (2020).

\subsection{Electricity system model}

Next, we model the electricity system to calculate electricity prices and congestion management costs, following the approach introduced in vom Scheidt et al. (2021).

For the uniform price scenario, we adapt a stylized meritorder and redispatch model from Staudt and Oren (2020). For each hour, the model minimizes the marginal generation costs for the entire single-price market area. The model's constraints ensure that demand and supply are balanced subject to the constraints that limit available generation capacity (26). Complying with the market designs of single-price markets, this model does not consider grid constraints. Therefore, the resulting market allocation can be technically infeasible, in which case redispatch measures ensue. The costbased redispatch mechanism begins at the existing market allocation and activates and deactivates generation capacity in the system until the cost-minimal solution is found that respects grid constraints which in the optimal case is equivalent to the nodal pricing solution (Staudt, 2019). Generators that are activated through this procedure are compensated based on their operating costs. The additional costs caused by this procedure are referred to as redispatch costs. In the considered idealized case, they are equivalent to the congestion management costs (27). The annotation for uniform, redispatch, and nodal pricing model are given in Table 3.

$$
\begin{aligned}
& \min \left(\sum_{t=1}^{T} \sum_{n=1}^{N} \sum_{g=1}^{G} q_{n, g, t} * p_{n, g}\right) \\
& \text { s.t. } \sum_{n=1}^{N} d_{g, t}=\sum_{n=1}^{N} \sum_{g=1}^{G} q_{n, g, t} \quad \forall t \in T \\
& q_{n, g, t} \leq c_{n, g, t} \quad \forall g \in G \quad \forall n \in N, \quad \forall t \in T
\end{aligned}
$$

$$
\begin{aligned}
& \min \left(\sum_{g=1}^{G} q_{g, t}^{\Delta} * p_{n, g}\right) \quad \forall t \in T \\
& \text { s.t. } \sum_{g=1}^{G} q_{g, t}^{\Delta}=0 \quad \forall t \in T \\
& \sum_{g=1}^{G}\left(q_{g, t}^{\Delta}+q_{g, t} \leq c_{g, t}\right) \quad \forall t \in T \\
& q_{g, t}^{\Delta}+q_{g, t} \geq 0 \quad \forall g \in G, \quad \forall t \in T \\
& \left.\mid \sum_{n=1}^{N} \sum_{g=1}^{G}\left(\left(\left(q_{n, g, t}+q_{n, g, t}^{\Delta}\right)-d_{n, t}\right) * H_{l, n}\right)\right) \mid \\
& \leq \tau_{l} \quad \forall l \in L, \quad \forall t \in T
\end{aligned}
$$

For the nodal price scenario, we use a nodal model with a DC-load flow approximation. This model simultaneously takes into account generation capacities and prices, as well as transmission capacities (28). Both models optimize each hour step-wise, independently of other hours. They thus neglect ramping and storage. 
Integrating Hydrogen in Single-Price Electricity Systems

$$
\begin{aligned}
& \min \left(\sum_{t=1}^{T} \sum_{n=1}^{N} \sum_{g=1}^{G} q_{n, g, t} * p_{n, g}\right) \\
& \text { s.t. } \sum_{n=1}^{N} d_{g, t}=\sum_{n=1}^{N} \sum_{g=1}^{G} q_{n, g, t} \quad \forall t \in T \\
& q_{n, g, t} \leq c_{n, g, t} \quad \forall g \in G \quad \forall n \in N, \quad \forall t \in T \\
& \left|\sum_{n=1}^{N} \sum_{g=1}^{G}\left(\left(q_{g, t}-d_{n, t}\right) * H_{l, n}\right)\right| \\
& \quad \leq \tau_{l} \quad \forall l \in L, \quad \forall t \in T
\end{aligned}
$$

Table 3

Notation for electricity system model

\begin{tabular}{ll}
\hline$q_{n, g, t}$ & Generation of unit $\mathrm{g}$ at node $\mathrm{n}$ at time $\mathrm{t}$ \\
$q_{n, g, t}^{\Delta}$ & Redispatch of unit $\mathrm{g}$ at node $\mathrm{n}$ at time $\mathrm{t}$ \\
$p_{n, g}$ & Marginal generation costs of unit $\mathrm{g}$ at node $\mathrm{n}$ \\
$d_{n, t}$ & Demand at node $\mathrm{n}$ at time $\mathrm{t}$ \\
$c_{n, g, t}$ & Generation capacity of unit $\mathrm{g}$ at node $\mathrm{n}$ (at time \\
& $\mathrm{t}$ for renewables) \\
$\tau_{l}$ & Transmission capacity of line I \\
$H$ & Matrix of power distribution factors \\
$N$ & Number of nodes $\mathrm{n}$ \\
$G$ & Number of generation units $\mathrm{g}$ \\
$L$ & Number of lines I \\
\hline
\end{tabular}

\section{Case study}

To demonstrate the functioning of the hydrogen model and the electricity model, we apply it to a case study. For this, we parametrize the models with data for the German electricity system and hydrogen demand in 2030.

\subsection{Hydrogen data}

In this subsection, we present all data sources, preprocessing steps, and assumptions used for creating the input data sets for demand, production, conversion, and transportation of hydrogen.

\subsubsection{Hydrogen demand}

In the following paragraphs, we describe data acquisition and preprocessing for the German hydrogen net demand in 2030. Hydrogen demand is assumed to come from the six following sectors: steel, ammonia, methanol, refinery, road transportation, and individual mobility. First, each demand sector is presented with general assumptions about future hydrogen demand and potential. Subsequently, the relevant locations of the respective sector with hydrogen demand in 2030 are identified. The estimated total hydrogen net demand amounts to 51.26 TWh. Table 11 in appendix B shows the numeric values and conversion factors used for the hydrogen demand calculations. For steel, ammonia, methanol, and refineries, $100 \%$ availability of the production facilities
Table 4

Estimated hydrogen net demand of primary steel producers in Germany, 2030

\begin{tabular}{ll}
\hline Steel producer & $\begin{array}{l}\text { Hydrogen net } \\
\text { demand [TWh] }\end{array}$ \\
\hline ArcelorMittal Bremen & 0.0 \\
ArcelorMittal Duisburg & 0.0 \\
ArcelorMittal Eisenhüttenstadt & 0.0 \\
ArcelorMittal Hamburg & 2.67 \\
ROGESA (Dillinger \& Saarstahl) & 2.16 \\
HKM Duisburg & 0.0 \\
Salzgitter Peine & 2.25 \\
Thyssenkrupp Steel Europe Duisburg & 6.17 \\
\hline Total & 13.25 \\
\hline
\end{tabular}

is assumed. Correspondingly, quantities that have been calculated down to hours are multiplied by 8,760 to get the respective annual quantity. For details on data acquisition and processing we refer to appendix A.

Steel Steel production in Germany offers a large potential for the use of hydrogen in industry by switching to hydrogenbased processes. In general, a distinction is made in steel production between primary and secondary steel as well as between blast furnace and electric arc routes (Hebling et al., 2019). Today, primary steel production is mainly based on coal- or coke-based processes to reduce iron ore in the blast furnace, resulting in large amounts of carbon emissions (Wilms et al., 2018). An alternative to the blast furnace is direct reduction, in which the iron ore is reduced by natural gas or hydrogen and $\mathrm{CO}_{2}$ emissions are directly avoided (Hebling et al., 2019). The product "direct reduced iron" (DRI) is further processed into steel in an electric arc furnace. If hydrogen is produced by electrolysis with electricity from renewable energies and used instead of coal in the direct reduction process, up to $95 \%$ of $\mathrm{CO}_{2}$ emissions could be avoided on the way to primary steel (Berger, 2020). In addition to the possibility of switching to direct reduction, $\mathrm{CO}_{2}$ emission reductions can be achieved by blowing in hydrogen as a substitute reducing agent. The basic idea is to reduce the amount of injection coal required and to replace it with hydrogen, in order to reduce $\mathrm{CO}_{2}$ emissions (thyssenkrupp, 2019). Depending on the operating conditions, emissions can be reduced by $21.4-28.5 \%$ compared to a reference case with today's standard operating mode (Yilmaz, 2018).

We identify all steel plants with potential for hydrogen use in 2030. Table 4 summarizes the hydrogen net demand of the steel industry. Based on the assumptions made, the total hydrogen net demand for 2030 amounts to 13.25 TWh and is distributed over Hamburg, Dillingen/Saar, Peine and Duisburg.

Ammonia Ammonia $\left(\mathrm{NH}_{3}\right)$ is produced using the HaberBosch process and requires the input components hydrogen $\left(\mathrm{H}_{2}\right)$ and nitrogen $\left(\mathrm{N}_{2}\right)$ (Hermann et al., 2014). The po- 
Integrating Hydrogen in Single-Price Electricity Systems

Table 5

Estimated hydrogen demand of ammonia producers in Germany, 2030

\begin{tabular}{ll}
\hline Ammonia producer & $\begin{array}{l}\text { Hydrogen net } \\
\text { demand [TWh] }\end{array}$ \\
\hline BASF Ludwigshafen & 5.18 \\
INEOS Köln & 2.25 \\
SKW Stickstoffwerke Piesteritz & 5.62 \\
YARA Brunsbüttel & 4.44 \\
\hline Total & 17.49 \\
\hline
\end{tabular}

Table 6

Estimated hydrogen net demand of methanol producers in Germany, 2030

\begin{tabular}{lr}
\hline Methanol producer & \multicolumn{2}{c}{$\begin{array}{l}\text { Hydrogen net } \\
\text { demand [TWh] }\end{array}$} \\
\hline BASF Ludwigshafen & 2.83 \\
Shell Rheinland Raffinerie - Süd & 2.74 \\
Ruhr Oel - BP Gelsenkirchen & 1.76 \\
Total Raffinerie Mitteldeutschland & 4.40 \\
\hline Total & 11.73 \\
\hline
\end{tabular}

tential for $\mathrm{CO}_{2}$ emissions reduction lies in replacing fossilgenerated hydrogen with electricity-based hydrogen. Today, hydrogen is mostly produced from steam methane reforming, with the by-product $\mathrm{CO}_{2}$. This byproduct can be used for processes in material composites, such as the production of urea (Hebling et al., 2019). Nevertheless, our estimation assumes a complete switch of ammonia production to electricity-based hydrogen in order to define an upper limit of hydrogen demand in the ammonia industry. Table 5 summarises the hydrogen demand of the ammonia industry. Based on the assumptions made, the total hydrogen demand is $17.49 \mathrm{TWh}$ and is distributed over four plants.

Methanol Currently, methanol is commonly produced using synthesis processes with $\mathrm{CO}_{2}$ emissions, which in future can be switched to hydrogen based processes (Michalski et al., 2019). Table 6 summarises the hydrogen demand of the methanol industry. Based on the assumptions made, the total hydrogen demand is $11.73 \mathrm{TWh}$ and is distributed over four sites.

Refineries In refineries, hydrogen is used on a large scale to desulfurize fuels and to refine heavy residues with hydrogen via hydrocracking (Hermann et al., 2014). The hydrogen needed for crude oil processing is supplied from internal and external sources. This means that refineries are partly self-sufficient, since hydrogen is a by-product of other processing operations (ENCON.Europe $\mathrm{GmbH}, 2018$ ). In this study, a $22 \%$ net demand for hydrogen is assumed, analogous to Wilms et al. (2018). This hydrogen net demand is assumed to be entirely served by electricity-based hydrogen in 2030, in line with Prognos AG (2020b). Table 7 summarises
Table 7

Estimated hydrogen net demand of refineries in Germany, 2030

\begin{tabular}{lr}
\hline Refinery & $\begin{array}{c}\text { Hydrogen net } \\
\text { demand [TWh] }\end{array}$ \\
\hline Bayernoil Raffineriegesellschaft & 0.19 \\
BP Raffinerie Lingen & 0.21 \\
Gunvor Raffinerie Ingolstadt & 0.22 \\
Holborn Europa Raffinerie & 0.23 \\
MiRO Mineraloelraffinerie Oberrhein & 0.66 \\
Nynas & 0.08 \\
OMV Deutschland & 0.16 \\
PCK Raffinerie & 0.51 \\
Raffinerie Heide & 0.19 \\
Ruhr Oel - BP Gelsenkirchen & 0.57 \\
Shell Rheinland Raffinerie Werk Nord & 0.41 \\
Shell Rheinland Raffinerie Werk Süd & 0.32 \\
Total Raffinerie Mitteldeutschland & 0.53 \\
\hline Total & 4.29 \\
\hline
\end{tabular}

the hydrogen net demand of the refineries in Germany 2030. The estimated total hydrogen net demand is $4.29 \mathrm{TWh}$ and is distributed over thirteen sites in Germany.

Transportation sector In the first step, we estimate total national hydrogen demand in the transport sector and the number of fueling stations required to satisfy the demand, including both road transportation with trucks and individual mobility with fuel cell passenger cars. In the second step, we spatially disaggregate this total demand and determine potential sites for fueling stations.

To determine the hydrogen demand for fuel cell trucks and passenger cars in Germany in 2030, we use the mean estimates from Fraunhofer-Institut (2019). We assume that heavy-duty trucks with a total weight above 12,000 kg (European Alternative Fuels Observatory) will be responsible for all truck based demand, because they have particularly high carbon emission savings potential and the fuel cell based version has stronger advantages over to their battery based counterparts, i.e. heavier payloads, longer ranges, and shorter recharging times (Weger et al., 2020). We assume the consumption of trucks to decrease to $8 \mathrm{~kg} / 100 \mathrm{~km}$ until 2030 , and that of fuel cell passenger cars to decrease to $0.63 \mathrm{~kg} / 100 \mathrm{~km}$, in line with Grube and Stolten (2018); FCH-JU (2017); Hyundai (2020). We assume that by 2030 all hydrogen stations will become L-size (IEA, 2015) with a capacity of 1,000 $\mathrm{kg}$ /day. According to Reuß et al. (2019), station investment cost is estimated considering scaling and learning effects, based on Equation (29). With the total number of fuel stations ( $\mathrm{n}$ ) determined in our model, a capacity of each fuel station $\mathrm{C}=1,000 \mathrm{~kg} / \mathrm{day}$, and the exogenous parameters $\alpha$, $\beta$, and $\gamma$ presented in Table 8 , we derive the investment cost per station for each hydrogen transportation state $s(s \in$ 
Table 8

Hydrogen station assumptions

\begin{tabular}{llll}
\hline & $\mathrm{GH} 2$ & $\mathrm{LH} 2$ & $\mathrm{LOHC}$ \\
\hline$\alpha[-]$ & 0.7 & 0.6 & 0.66 \\
$\beta[-]$ & 0.06 & 0.06 & 0.06 \\
$\gamma[-]$ & 0.6 & 0.9 & 1.4 \\
$\mathrm{EC}\left[\mathrm{kWh} h_{e l} / \mathrm{kg}_{\mathrm{H}_{2}}\right]$ & 1.6 & 0.6 & 4.4 \\
$\mathrm{NGC}\left[\mathrm{kWh} h_{\mathrm{NG}} / \mathrm{kg}_{\mathrm{H}_{2}}\right]$ & 0 & 0 & 11.7 \\
Depreciation years $[a]$ & 10 & 10 & 10 \\
O\&M [\%] & 5 & 5 & 5 \\
\hline
\end{tabular}

$\{G H 2, L H 2, L O H C\})$.

$$
\begin{array}{r}
I S_{S}=1.3 * 600,000 E U \\
R * \gamma *\left(\frac{C}{212 k g / \text { day }}\right)^{\alpha} \\
*(1-\beta)^{\log _{2}\left(\frac{C * n}{212 k g / d a y * 400}\right)}
\end{array}
$$

Next, we identify the number and locations of fueling stations. Since passenger cars and trucks have different driving and refueling patterns, we separately select their fuel station locations.

For passenger cars, we assume a utilization of $70 \%$ and thus a turnover of $700 \mathrm{~kg}_{\mathrm{H}_{2}}$ per day, in line with Reuß et al. (2019). This results in 412 fueling stations for cars. We then first disaggregate the total demand to the $>400$ German NUTS-2 regions proportionally to the NUTS-2 gross domestic product (GDP). Since no more granular GDP data exists, we further break down the hydrogen demand to the over 10,000 NUTS-3 regions in Germany proportionally to the population in that NUTS-3 region. Currently, there are 72 hydrogen fueling stations (October 2019) in Germany ( $\mathrm{H} 2$ MOBILITY, 2019). Since these will not suffice to satisfy demand in 2030, we assume that additional fueling stations will be installed at the same locations as existing gasoline stations. Therefore, we use the 11,285 gasoline stations from OpenStreetMap as further potential sites (OpenStreetMap Contributors, 2020). For each of these stations, we calculate the distance to the closest NUTS-3 region center. For each NUTS-3 region, we then select stations with the shortest distance to its center, until its demand is covered.

For trucks, Rose and Neumann (2020b) determine optimal hydrogen fuel station locations along highways under consideration of traffic flow and capacity limits. From these locations, we adopt those with highest utilization rate, which leads to 97 stations. We assume all fuel stations have 1,000 $\mathrm{kg} /$ day capacity and have the same turnover. Thus, to meet the demand from fuel cell heavy-duty trucks, the turnover of each fuel station is $847.42 \mathrm{~kg}_{\mathrm{H}_{2}}$ per day.

Summary of hydrogen demand The total hydrogen net demand in 2030 is estimated to be 51.26 TWh. Figure 2 displays the hydrogen net demands of the individual sectors. The map in Figure 3 shows the geographic distribution of the hydrogen demand, with the size of the markers corresponding to demand volume.

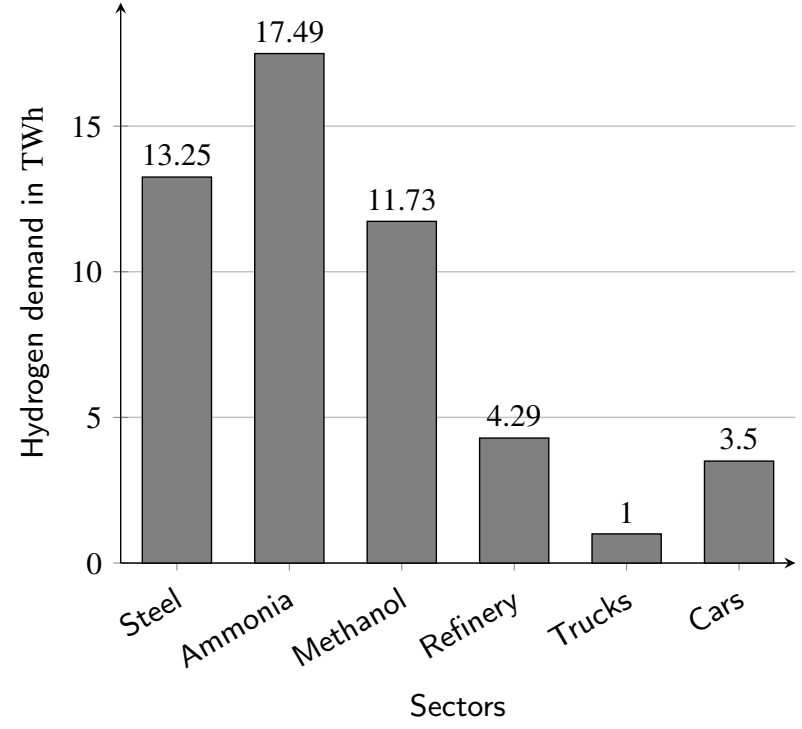

Figure 2: Estimated hydrogen net demand per sector in Germany, 2030

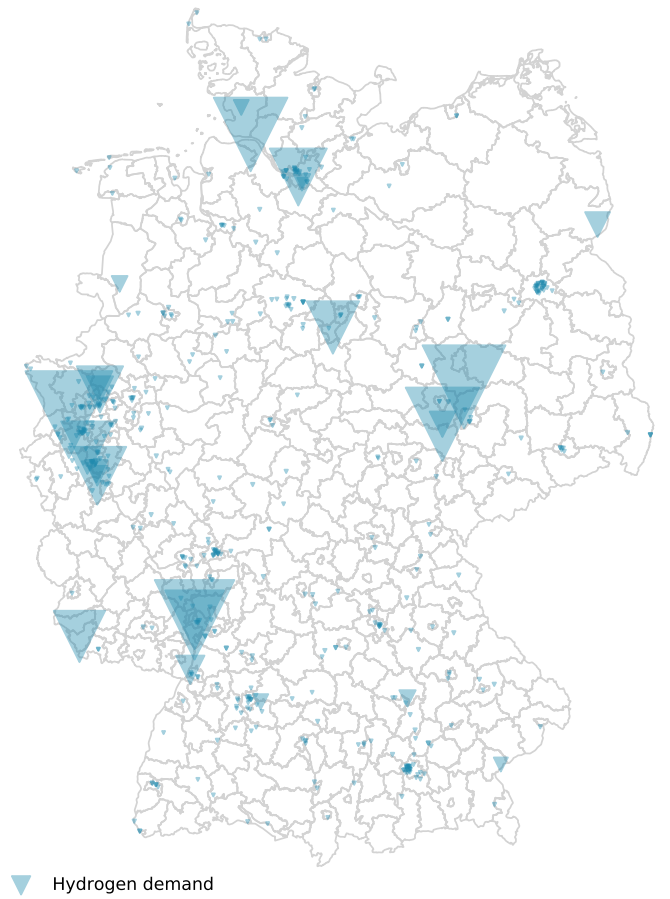

Figure 3: Spatial distribution of estimated hydrogen net demand in Germany, 2030

\subsubsection{Hydrogen production and import data}

Electrolysis is the main pillar of political strategies for hydrogen supply in Germany (Federal Government of Germany, 2020) and the European Union (European Commission, 2020). Among the different electrolysis technologies, proton exchange membrane (PEM) electrolysis is projected to have the lowest CAPEX and highest efficiency in 2030 (Böhm et al., 2020). Therefore, we focus on PEM electroly- 
sis for hydrogen production. As input for the hydrogen supply chain model, we assume investment costs $I C_{\text {Electrolyzer }}$ of $604 \mathrm{EUR} / k W_{e l}$, depreciation over 10 years, O\&M costs of $4 \%$ of investment costs and electricity consumption $E C$ of $47.6 \mathrm{kWh}$ el per $k g_{H 2}$, based on Schmidt et al. (2017); Brown et al. (2018); Reuß et al. (2019). Electrolyzer efficiency $E E$ is set to $70 \%$ (Robinius et al., 2017; Reuß et al., 2019). We set the minimum capacity $C A P_{\text {Production,min }}$ to $10 \mathrm{MW}$ and the maximum capacity $C A P_{\text {Production,max }}$ to 100 MW. ${ }^{3}$ Regarding operation we analyze two different cases. In the main case, all electrolyzers are assumed to operate continuously at $70 \%$ of full capacity, which is within typical ranges (Robinius et al., 2017; Guerra et al., 2019; Ruhnau, 2020)). In a sensitivity case, all electrolyzers are assumed to have temporal flexibility which allows them to shift their operation to hours with cheap wholesale electricity prices. In this "FlexOp" case we assume they run at $100 \%$ during the $70 \%$ cheapest hours. Thus, in both cases, the total volume of produced hydrogen is the same.

The potential locations for electrolyzers are equal to the set of transmission grid nodes from our electricity system model (compare Section 4.2.1). ${ }^{4}$ Besides, we include hydrogen imports from overseas into our model, since they are a key part of the German hydrogen strategy (Federal Government of Germany, 2020). For these imports, we assume a fixed, exogenous amount of daily available imported hydrogen of $27.40 \mathrm{GWh}$ and costs of $3.48 \mathrm{EUR} / \mathrm{kg}_{\mathrm{H}_{2}}$, in line with the mean values reported by Runge et al. (2020). Furthermore, we assume that all imports to Germany will occur at one large port, i.e. Bremerhaven, in line with Runge et al. (2020).

\subsubsection{Hydrogen conversion data}

Hydrogen can be converted to compressed state (GH2), liquefied (LH2), or stored into chemicals (LOHC) for transportation via tube trailers. Notably, for LH2 and LOHC, there are capital and operating costs at the point of hydrogen production (for liquefaction, and hydrogenation, respectively) and at the point of hydrogen consumption (evaporation, and dehydrogenation, respectively).

The assumptions regarding investment costs, depreciation years, O\&M costs, electricity and natural gas consumption, and losses are displayed in Table 9.

\subsubsection{Hydrogen transportation data}

Transportation costs include costs for fuel, toll, and the drivers' wages. Fuel consumption of a delivery truck is assumed to be $34.1 l_{\text {diesel }} / 100 \mathrm{~km}$ (Shell, 2016). We assume a diesel price in 2030 of $2.66 \mathrm{EUR} / \mathrm{l}$, which includes the net diesel price (1.73 EUR/l), mineral oil tax (0.47 EUR/l), oil stockpiling fee ("Erdölbevorratungsbeitrag") (0.30 EUR/l),

\footnotetext{
${ }^{3}$ This range was determined based on a review of 45 existing and currently planned projects in Germany.

${ }^{4}$ Such large-scale electrolyzers might be complemented by smaller, onsite electrolyzers (see, e.g. Rose and Neumann (2020b); Golla et al. (2020)) in practice. Such on-site electrolyzers would be connected to the distribution grid. Analyzing congestion consequences at distribution grid level is out of scope of this study.
}

and emission tax (0.16 EUR/l).

In line with Reuß (2019), we make the following cost assumptions. Toll is set to $0.15 \mathrm{EUR} / \mathrm{km}$. Drivers' wage is set to $35 \mathrm{EUR} / \mathrm{h}$. Average driving speed is set to $50 \mathrm{~km} / \mathrm{h}$. Truck investment costs are set to $160,000 \mathrm{EUR}$, with depreciation over eight years and $12 \%$ O\&M costs. For tube trailers, investment costs and capacities are technology specific. They are set to 660,000 EUR and 1,100 $\mathrm{kg}_{\mathrm{H}_{2}}$ for gaseous hydrogen (GH2), 860,000 EUR and 4,300 $\mathrm{kg}_{\mathrm{H}_{2}}$ for liquefied hydrogen (LH2), and to 150,000 EUR and 1,620 $\mathrm{kg}_{\mathrm{H}_{2}}$ for LOHC. Besides, we assume depreciation over twelve years and O\&M costs of $2 \%$, adopted from Reuß et al. (2019).

\subsection{Electricity system data}

We parametrize both, the uniform price and the nodal price electricity model with data for generation, consumption and the transmission grid in 2030. For this, we utilize the data set published by vom Scheidt et al. (2020). In the following, we briefly describe this data set. All data are more elaborately documented and available for free use under a Creative Commons license in vom Scheidt et al. (2020).

\subsubsection{Transmission grid data}

The transmission grid in 2030 is constructed from the reference ELMOD model of the existing grid, which is enhanced with all the expansions and new installations until 2030 that have been announced by the German Federal Network Agency. The resulting final grid representation consists of 485 nodes and 663 lines. The transmission capacity of all $220 \mathrm{kV}$ lines is set to $490 \mathrm{MW}$, and that of all $380 \mathrm{kV}$ lines to 1700 MW, based on Egerer (2016); Kießling et al. (2011).

\subsubsection{Electricity demand data}

For consumption, the hourly consumption forecast scenario EUCO30 is used (European Network of Transmission System Operators for Electricity, 2018). To improve consistency of grid and consumption data, these hourly values are re-scaled so that the annual total $(577 \mathrm{TWh})$ matches the sum used in the official grid development plan (544 TWh) by Bundesnetzagentur (2019a).

Next, these re-scaled hourly demand values are spatially disaggregated to NUTS-3 levels. For this disaggregation, the gross domestic product (GDP) and the population of a region serve as proxies for its future electricity consumption. The resulting NUTS- 3 consumption time series are assigned to the nearest grid node.

\subsubsection{Electricity generation data}

For generation, estimation is differentiated between renewable, i.e. non-dispatchable generation, and dispatchable generation.

For renewable generation, i.e. solar and wind, historical hourly generation data from the four national grid operators (Bundesnetzagentur, 2018) is used. These hourly values are 
Table 9

Conversion assumptions, based on Reuß et al. (2019); Nexant et al. (2008). $x$ denotes daily hydrogen output.

\begin{tabular}{|c|c|c|c|c|c|c|}
\hline & Investment [EUR] & $\begin{array}{l}\text { Depreciation } \\
\text { years }\end{array}$ & O\&M & $\begin{array}{l}E C_{\text {Conversion }} \\
{\left[k W h_{e l} / k g_{H_{2}}\right]}\end{array}$ & $\begin{array}{l}N G C_{\text {Conversion }} \\
{\left[k W h_{N G} / k g_{H_{2}}\right]}\end{array}$ & Loss $[\%]$ \\
\hline Compressor & $15 * 10^{3} \frac{E U R}{k W} * x^{0.6089} * 3$ & 15 & $4 \%$ & calculated & 0 & 0.5 \\
\hline Liquefaction & $105 * 10^{6} E U R *\left(\frac{x}{50 \frac{{ }^{t} H_{2}}{d a y}}\right)^{0.66}$ & 20 & $4 \%$ & 6.78 & 0 & 1.65 \\
\hline Evaporation & $3 * 10^{3} E U R * \frac{x}{1000}$ & 10 & $3 \%$ & 0.6 & 0 & 0 \\
\hline Hydrogenation & $40 * 10^{6} E U R *\left(\frac{x}{300 \frac{{ }^{t} H_{2}}{d a \gamma}}\right)^{0.66}$ & 20 & $3 \%$ & 0.37 & 0 & 1 \\
\hline Dehydrogenation & $30 * 10^{6} E U R *\left(\frac{x}{300 \frac{{ }^{t} H_{2}}{d a y}}\right)^{0.66}$ & 20 & $3 \%$ & 0.37 & 11.7 & 1 \\
\hline
\end{tabular}

re-scaled so that the annual total generation from each technology matches the sum used in the grid development plan (Bundesnetzagentur, 2019a). This results in an annual generation of 86.7 TWh from solar (compared to an mean of 35.34 TWh in 2016-2018), and of 247.4 TWh from wind (compared to an mean of 108.6 TWh in 2016-2018). Next, the re-scaled hourly generation values are spatially disaggregated. For this, we use the installed generation capacity per zip code as provided by Deutsche Übertragungsnetzbetreiber (2018).

For dispatchable electricity generation capacity, all relevant plants for 2030 from the power plant list of the German grid regulator are used (Bundesnetzagentur, 2019b). For each plant, marginal costs are calculated, based on fuel type, estimated efficiency, and emissions costs. A $\mathrm{CO}_{2}$ price of $60 \mathrm{EUR} /$ ton is assumed (Bundesregierung, 2019).

Both renewable generation time series and dispatchable power plants, along with their marginal costs, are assigned to the nearest grid node. Note that this approach provides high spatial granularity, but comes at the costs of treating Germany as an isolated system without cross-border electricity lines. This can affect the results for electricity prices and redispatch in both directions (Xiong et al., 2021). Therefore, a geographic expansion - e.g. a European model - can be worthwhile future work, but requires substantial additional data procurement efforts if the high spatial granularity (i.e. 485 nodes in the German system) is to be upheld. A starting point could be the open network model PyPSA-Eur-Sec-30 that works with one node per country (Victoria et al., 2019).

\section{Results and Discussion}

Upon parametrizing the models presented in Chapter 3 with the case study data presented in Chapter 4, we run the models in three steps. First, we derive baseline results for the electricity system without hydrogen, including wholesale uniform prices, nodal prices and congestion management costs. Second, based on the resulting electricity prices, we derive information about the optimal hydrogen supply chains, including total end-use costs of hydrogen, as well as number, capacities and locations of electrolyzers. Third, we observe the effects of integrating these hydrogen supply chains in the electricity system, including changes in total electricity demand, wholesale prices, and redispatch costs.

\subsection{Baseline electricity system results}

Without the integration of hydrogen the resulting annual mean of the wholesale uniform price is $62.61 \mathrm{EUR} / \mathrm{MWh}$. Figure 4 shows the price duration curve. The annual redispatch costs are 6.16 Billion EUR. The resulting annual means of nodal prices vary between -54.30 and +221.00 EUR/MWh, with a median value of $67.80 \mathrm{EUR} / \mathrm{MWh}$. Figure 5 shows the spatial distribution of nodal prices.

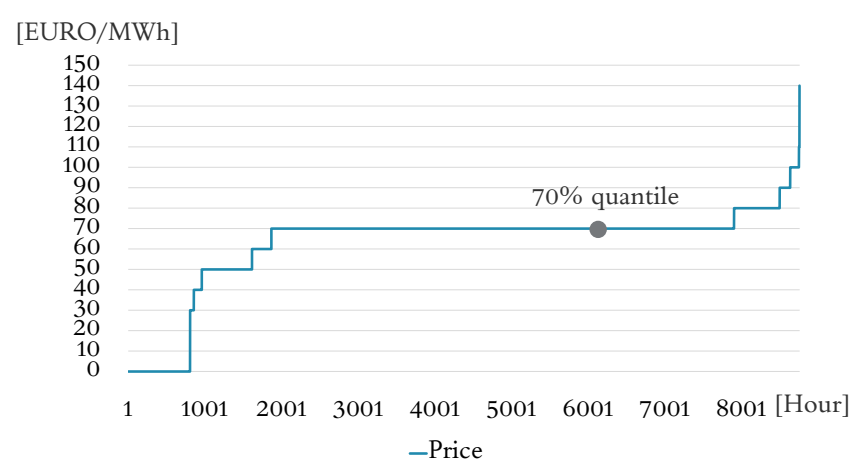

Figure 4: Wholesale price duration curve in Germany, 2030 [EUR/MWh]

Low prices are predominantly found in the North-East and North-West of the country, driven by high renewable generation and low demand. This finding is in line with Robinius et al. (2017) who analyze residual loads on county level and find negative residual loads predominantly in the North-East and North-West.

\subsection{Hydrogen supply chain results}

The resulting end-use costs for hydrogen are represented in Figure 6. In the uniform pricing scenario, the final hydrogen costs for industry applications are $5.98 \mathrm{EUR} / \mathrm{kg}_{\mathrm{H}_{2}}$ for $\mathrm{GH} 2$, $4.30 \mathrm{EUR} / \mathrm{kg}_{\mathrm{H}_{2}}$ for $\mathrm{LH} 2$, and $4.68 \mathrm{EUR} / \mathrm{kg}_{\mathrm{H}_{2}}$ for LOHC. For trucks and cars, costs for fueling stations need to be added, resulting in final hydrogen costs of 6.14 $E U R / k_{H_{2}}$ for GH2, $4.41 E U R / k_{H_{2}}$ for LH2, and 5.89 


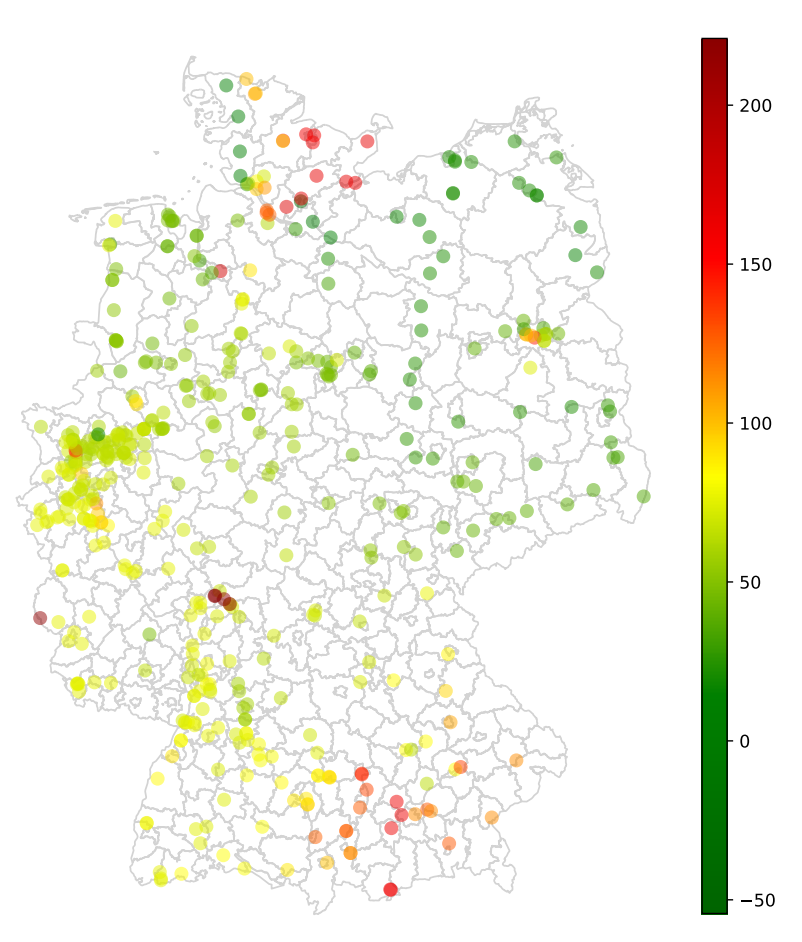

Figure 5: Shadow nodal prices in Germany, 2030 [EUR/MWh]

$E U R / \mathrm{kg}_{\mathrm{H}_{2}}$ for LOHC. The largest share of costs are caused by hydrogen production in all cases.

For the cheapest form, i.e. LH2, we additionally compute the FlexOp scenario, in which electrolysis is shifted to hours with cheaper prices. As Figure 4 shows, this includes prices in the range of $0-70$ EUR/MWh. For LH2 this shift decreases total hydrogen costs by $5.30 \%$, i.e. from $4.30 \mathrm{EUR} / \mathrm{kg}_{\mathrm{H}_{2}}$ to $4.07 \mathrm{EUR} / \mathrm{kg}_{\mathrm{H}_{2}}$.

In the scenario with nodal pricing costs are much more reduced, to 3.55 (3.71 for trucks and cars) EUR/ $\mathrm{kg}_{\mathrm{H}_{2}}$ for $\mathrm{GH} 2,2.73$ (2.84) $\mathrm{EUR} / \mathrm{kg}_{\mathrm{H}_{2}}$ for $\mathrm{LH} 2$, and 3.32 (4.53) $\mathrm{EUR} / \mathrm{kg}_{\mathrm{H}_{2}}$ for LOHC.

Figures 7 and 8 depict the resulting locations of electrolyzers. The size of the markers corresponds to production volume. The largest marker in the North-East depicts overseas imports, which are exogenously determined (compare Chapter 4.1.2) and thus occur equally in all scenarios.

Under uniform pricing with LH2, 102 domestic electrolyzers are placed, all of which close to points of consumption, in order to minimize transportation costs. Of these, roughly the half (52) have the maximal possible capacity of $100 \mathrm{MW}$.

Under nodal pricing, electrolyzers are placed further away from consumption, but at nodes with the cheapest electricity prices. In the LH2 nodal case, 71 electrolyzers are placed, of which 66 have maximal possible capacity. This indicates that the cheaper electricity costs outweigh the higher transportation operating costs. This effect is stable across the three delivery states, in line with the preliminary findings by vom Scheidt et al. (2021).

\subsection{Integration results}

From the above presented locations and capacities of electrolyzers, we calculate the additional electricity demand from hydrogen production at each grid node. With this new input, we recalculate electricity prices and congestion management costs to identify the effects of hydrogen on the electricity system. For these calculations we assume LH2 delivery, since it is the cost-minimal hydrogen supply chain set-up under both price scenarios and for both industry and transportation applications.

Table 10 summarizes the key results. The electrolytic production of hydrogen creates considerable new electricity demand of 58,92 TWh per year that increases the total national electricity demand by about $11 \%$. This lead to rising wholesale prices. Compared to the benchmark scenario without hydrogen, mean annual wholesale prices rise by $10.33 \%$ with continuously operating electrolyzers, and by $10.76 \%$ with flexibly operation electrolyzers.

Under the uniform price, annual congestion management costs increase by $11 \%$. Interestingly, this increase occurs for static as well as for flexible electrolyzers that respond to uniform wholesale prices. This finding indicates that electrolyzers which respond to wholesale prices, but are inefficiently placed from a system perspective might not be able to realize the often expected positive impacts (e.g. regarding the usable share of renewable energy Ruhnau (2020)) due to grid constraints. A key explanatory factor for this might be that wind generation, which to a large extend is located in the North of Germany (Deutsche Übertragungsnetzbetreiber, 2018) has been shown to drive wholesale prices down (Benhmad and Percebois, 2018) and at the same time drives congestion in the transmission grid (Staudt et al., 2019). Nevertheless, dedicated analyses are needed to validate this finding, as the focus of our study is the spatial dimension. Therefore, we consider a more comprehensive combination of spatial and temporal dimension a promising direction for future work on hydrogen integration.

In contrast, when electrolyzers are placed under nodal price signals, they decrease congestion management costs by $-23.71 \%$ or 1,462 million Euros. This represents a delta of over 2 billion Euros per year between the two scenarios of hydrogen integration. In other words, the production of one $\mathrm{kg}_{\mathrm{H}_{2}}$ on average creates additional congestion costs of 0.44 Euros under current regulation, whereas it reduces congestion costs by 0.95 Euros under more efficient regulation. This means a spatially differentiated subsidy for hydrogen production (e.g. in the form of a per-kWh payment of the spread between uniform prices and simulated nodal prices) could largely be covered by saved redispatch costs.

One limitation of the generalizability our findings comes from the focus on one technology for hydrogen production, i.e. electrolysis. Hydrogen from steam methane reforming with carbon capture and storage represents an alternative of producing hydrogen with net neutral emissions and can be an economic alternative to electrolytic hydrogen, depending 


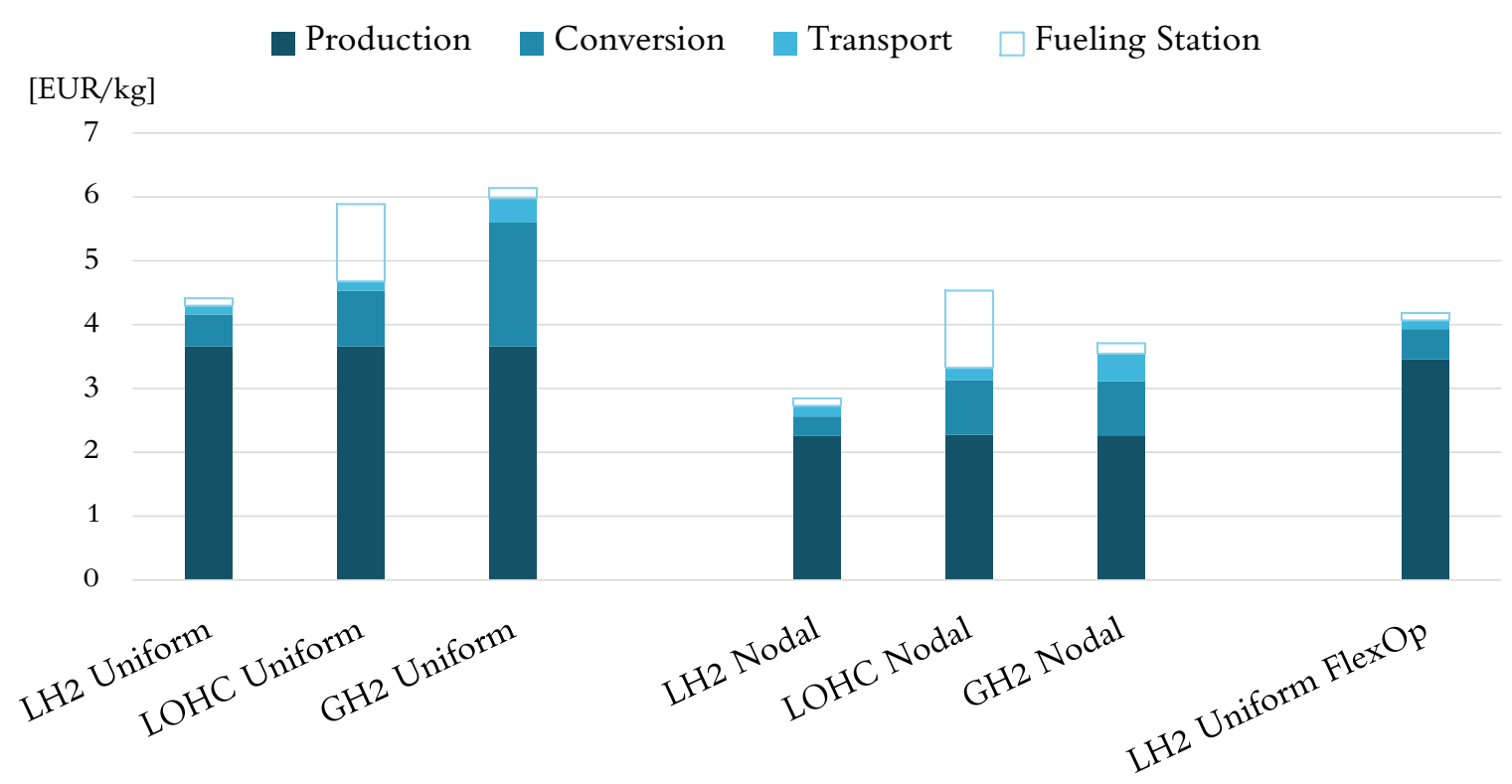

Figure 6: End-use hydrogen costs by component and scenario

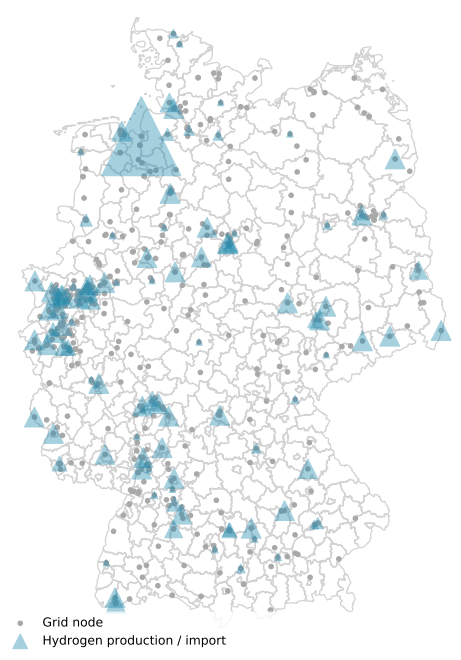

(a) Delivery with GH2 Trailers

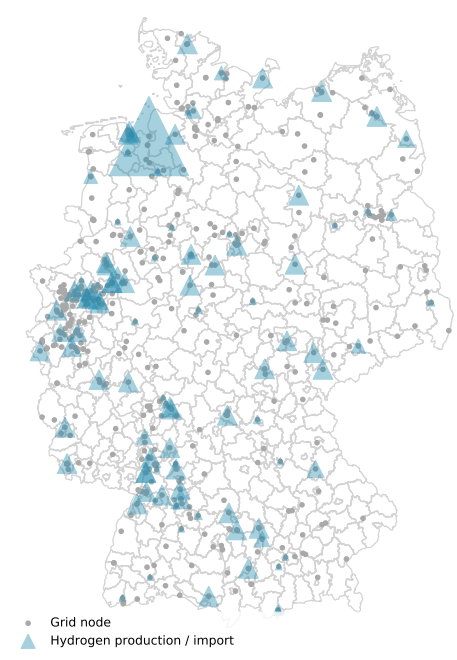

(b) Delivery with LH2 Trailers

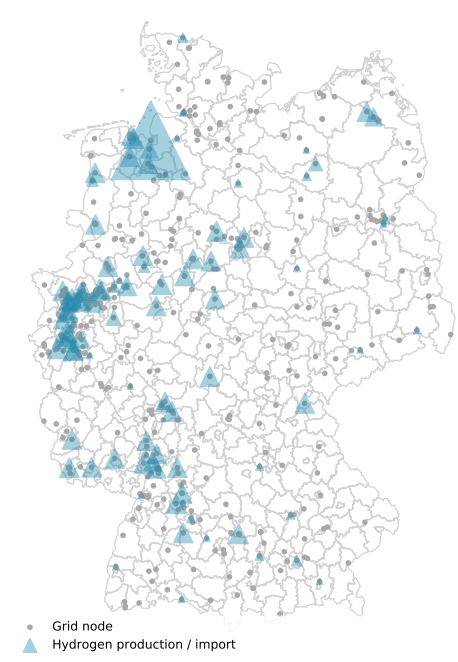

(c) Delivery with LOHC Trailers

Figure 7: Optimal electrolyzer locations under uniform electricity prices

on political and geographic circumstances (see e.g. Bødal et al. (2020)). In the German case, however, political action is strongly focused on electrolysis (Federal Government of Germany, 2020).

Another interesting avenue for the expansion of this work is the effect of electrolysis on system emissions. While quantifying this effect is out of this study's scope, we expect that the decrease in congestion enabled by electrolyzers placed according to nodal prices will also lead to a decrease in emissions, since a considerable, and rising share of curtailed energy comes from renewable sources (Xiong et al., 2021).

\section{Conclusions and Policy Implications}

Policymakers in dozens of countries are currently planning public funding for the development of future hydrogen infrastructure. They can expect that the integration of hydrogen into electricity systems will have a large effect on the operation of these systems. Our study sheds some light on the effects of hydrogen integration, and the role of spatial economic signals.

For this, we propose a three-step methodology based on linking an electricity system dispatch model and a hydrogen supply chain model, both with granular spatial resolution. 


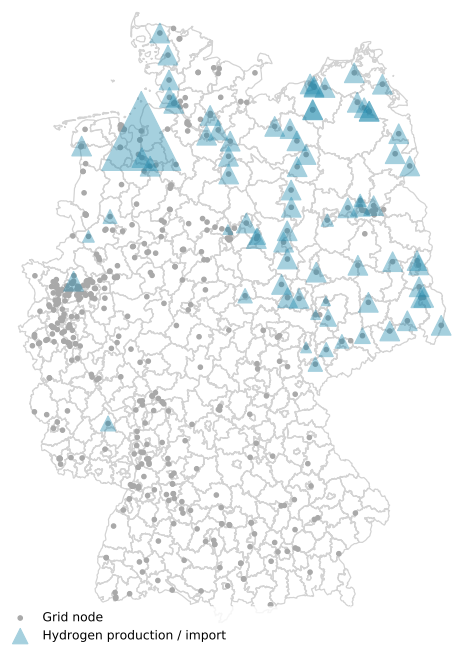

(a) Delivery with GH2 Trailers

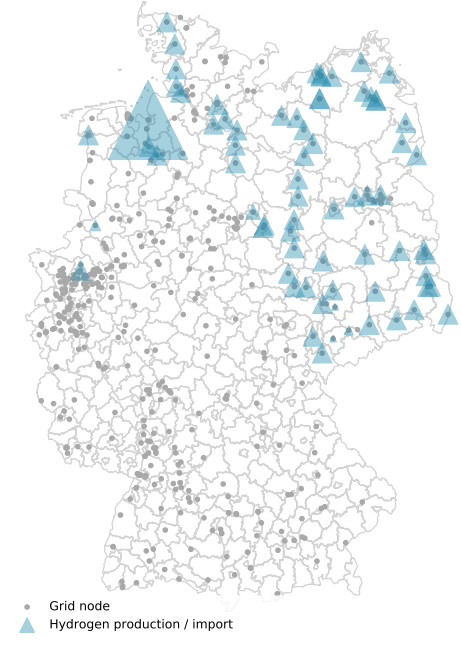

(b) Delivery with LH2 Trailers

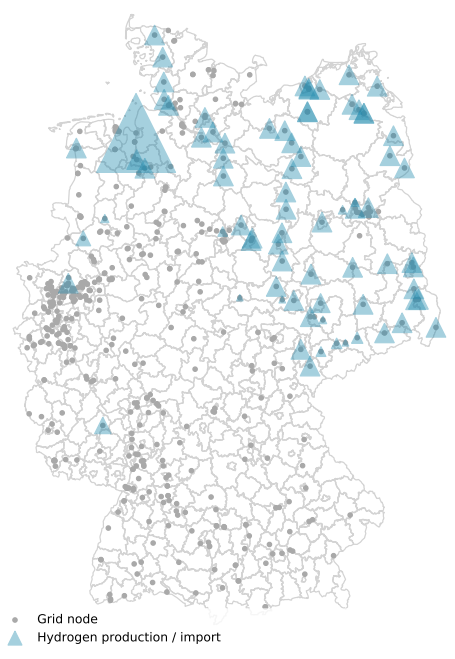

(c) Delivery with LOHC Trailers

Figure 8: Optimal electrolyzer locations under nodal electricity prices

Table 10

Electricity demand, wholesale price and congestion management costs in 2030

\begin{tabular}{llll}
\hline & $\begin{array}{l}\text { Total electricity demand } \\
\text { [TWh/year] }\end{array}$ & $\begin{array}{l}\text { Mean wholesale price } \\
\text { [EUR/MWh] }\end{array}$ & $\begin{array}{l}\text { Congestion management } \\
\text { costs [MEUR/year] }\end{array}$ \\
\hline Baseline without $\mathrm{H}_{2}$ & 543.90 & 62.61 & $6,163.96$ \\
With $\mathrm{H}_{2}$ under Uniform Price & $602.82(+10.83 \%)$ & $69.07(+10.33 \%)$ & $6,839.06(+10.95 \%)$ \\
With $\mathrm{H}_{2}$ under Uniform Price (FlexOp) & $602.82(+10.83 \%)$ & $69.34(+10.76 \%)$ & $6,852.58(+11.17 \%)$ \\
With $\mathrm{H}_{2}$ under Nodal Price & $602.82(+10.83 \%)$ & $69.07(+10.33 \%)$ & $4,702.22(-23.71 \%)$ \\
\hline
\end{tabular}

We apply this methodology for a case study of the German system in 2030 .

In the first step, we use the electricity system dispatch model to simulate uniform electricity prices - representing current regulation - and nodal prices, without considering hydrogen demand and production.

In the second step we feed those prices into the hydrogen model, together with additional techno-economic parameters for capital and operation costs. This way, we determine the optimal spatial design of hydrogen supply chains under current uniform regulation, and a regulation with efficient spatial price signals. We identify liquefied hydrogen as the most economical form of truck based hydrogen delivery in all scenarios. Furthermore, we find that under current uniform prices, electrolyzers are cost-minimally placed close to consumption points, such as industry plants and large cities. In the alternative nodal pricing scenario, we find that the price differences among nodes are large enough to move hydrogen production to low-cost nodes that are further away from consumption points and closer to low-cost electricity generation capacity.

In the third step, we feed back the resulting electric loads from electrolyzers into the electricity system dispatch model.
The results show that the integration of hydrogen under current uniform prices causes a large increase in congestion management costs of about $11 \%$, or 675 million Euros per year. Thus, our analysis shows that the existing inefficiencies of single-price zonal markets can be strongly aggravated by hydrogen. Given efficient spatial signals, electrolyzers are integrated in a much more system-friendly way and actually decrease congestion management costs by $24 \%$, or about 1,462 million Euros per year, compared to the benchmark scenario without hydrogen. This is important information for policy makers in single-price electricity markets that intend to subsidize hydrogen, as our results demonstrate the considerable benefits of spatially differentiated subsidies. In fact, the subsidies a regulator would have to pay to mimic nodal prices for hydrogen within the existing single-price market design could almost entirely be covered from avoided redispatch costs.

Given prevailing political barriers to introducing nodal pricing markets in Europe (European Network of Transmission System Operators for Electricity, 2021) it is important to note that policy makers can still incorporate our findings within the existing single-price markets. For instance, they could offer a specific nodal tariff which bills electrolyzers based on shadow nodal prices instead of wholesale prices. Alternatively, if subsidies in the form of reduced per-kWh 
prices are planned (like in the German Hydrogen Strategy (Federal Government of Germany, 2020)), those can be limited to electrolyzers that are connected to nodes with low shadow nodal prices. Another approach could be to allow grid operators in case of congestion to curtail electrolyzers before performing the regular redispatch measures, thus creating an incentive for electrolyzer investors to avoid frequently curtailed nodes of the grid. Given the large potential benefits identified in this study, an interesting avenue for future work certainly lies in investigating the solution space of economically efficient, and politically feasible mechanisms for the integration of hydrogen in single-price electricity systems.

\section{CRediT authorship contribution statement}

Frederik vom Scheidt: Conceptualization, Methodology, Software, Formal analysis, Investigation, Data Curation, Writing - Original Draft, Writing - Review \& Editing, Visualization, Project administration. Jingyi Qu: Software, Resources, Data Curation, Visualization, Writing - Review \& Editing. Philipp Staudt: Conceptualization, Writing - Review \& Editing, Supervision, Funding acquisition. Dharik S. Mallapragada: Conceptualization, Writing - Review \& Editing. Christof Weinhardt: Resources, Supervision, Funding acquisition.

\section{Acknowledgements}

We thank Julian Huber and Marc Schmidt for their advice on efficiently deploying the electricity system dispatch model. We thank Jürgen Beck for assistance with the procurement of hydrogen demand data.

\section{References}

Agora Energiewende, Wuppertal Institut, 2019. Klimaneutrale Industrie: Schlüsseltechnologien und Politikoptionen für Stahl, Chemie und Zement. Berlin, Wuppertal: Agora Energiewende .

Antenne Brandenburg, $2020 . \quad$ Arcelormittal verpflichtet sich zur klimaneutralen Stahlproduktion. URL: https://www.rbb24.de/studiofrankfurt/beitraege/2020/07/ eisenhuettenstadt-arcelormittal-stahl-wasserstoff.html.

ArcelorMittal, 2017. Wasserstoff-Stahl: ArcelorMittal und HAW Hamburg legen Studie vor. URL: https://hamburg. arcelormittal.com/icc/arcelor-hamburg-de/ broker. jsp?uMen $=9 d 0 f 6 f b b-a 799-5199-f 8 b 4-947 d 7 b 2 f 25 d 3 \&$ uCon=7c010c15-a102-cd51-db2a-9147d7b2f25d\&uTem= aaaaaaa- aaaa- aaaa- aaaa-000000000011.

ArcelorMittal, 2020a. Hamburg: WasserstoffProjekt mit konkreter Planung. URL: https:// hamburg. arcelormittal.com/icc/arcelor-hamburg-de/

broker.$j$ sp? ? Men $=9 d 0 f 6 \mathrm{fbb}-\mathrm{a} 799-5199-\mathrm{f} 8 \mathrm{~b} 4-947 \mathrm{~d} 7 \mathrm{~b} 2 \mathrm{f} 25 \mathrm{~d} 3 \&$

uCon=efe $407 a 1-7 e 2 f-4171-5933-6 e b 4 b a 5 c 485 d \& u T e m=$

aаaаaаaа- аaаa- аaаa- аaаa- 000000000011 .

ArcelorMittal, 2020b. Pressemitteilung: ArcelorMittal Europe will noch 2020 den ersten grünen Stahl produzieren. URL: https://bremen.arcelormittal.com/icc/ arcelor-bremen-de/med/454/454205d9-81ba-1571-0202-ac33ef90c5de, 11111111-1111-1111-1111-111111111111. pdf.
BASF, 2020. Interview Methanpyrolyse. URL: https: //www. basf.com/global/de/who-we-are/sustainability/ we-produce-safely-and-efficiently/energy-and-climate-protection/ carbon-management/interview-methane-pyrolysis.html.

Bazzanella, A., Ausfelder, F., 2017. Low carbon energy and feedstock for the European chemical industry. DECHEMA, Gesellschaft für Chemische Technik und Biotechnologie eV.

Benhmad, F., Percebois, J., 2018. Photovoltaic and wind power feed-in impact on electricity prices: The case of germany. Energy Policy 119, 317-326. URL: https://www. sciencedirect.com/science/article/pii/ S0301421518302581, doi:https://doi .org/10.1016/j. enpol.2018.04.042.

Berger, C., 2020. 95 Prozent weniger $\mathrm{CO} 2$ bei der Stahlproduktion. URL: https://www. springerprofessional.de/anlagenbau/ rohstoffe/95-prozent-weniger-co2-bei-der-stahlproduktion/18437776.

Bezirksregierung Köln, 2017. Genehmigungsbescheid: Wesentliche Änderung der Anlage zur Herstellung von Ammoniak (AmmoniakAnlage) auf dem Werksgelände Köln der Firma INEOS Köln GmbH. URL: https: //www. bezreg-koeln. nrw. de/brk_internet/verfahren/52_53_ industrieanlagen_genehmigungen/bekanntmachungen_koeln/ineos_koeln_ gmbh_201612021/bescheid. pdf.

Böhm, H., Zauner, A., Rosenfeld, D.C., Tichler, R., 2020. Projecting cost development for future large-scale power-to-gas implementations by scaling effects. Applied Energy 264, 114780.

BP, 2019. Zahlen \& Fakten: Produktion. URL: https://www.bp.com/de_ de/germany/home/wo-wir-sind/raffinerie-gelsenkirchen/wer-wir-sind/ zahlen-und-fakten.html.

Brown, T., Schlachtberger, D., Kies, A., Schramm, S., Greiner, M., 2018. Synergies of sector coupling and transmission reinforcement in a costoptimised, highly renewable european energy system. Energy 160, 720 739. doi:https://doi.org/10.1016/j. energy. 2018.06.222.

Bundesnetzagentur, 2018. Marktdaten. Retrieved from https: / /www. smard. de/home/downloadcenter/download_marktdaten/ $726 \#$ ! ?downloadAttributes=\%78\%22selectedCategory $\% 22: 1$,

$\% 22$ selectedSubCategory $\% 22: 8$, \%22selectedRegi on $\% 22: \% 22$ DE $\% 22$, \%22from $\%$ 22:1546297200000, \%22to\%22: $1577833199999, \% 22$ selectedFileType\%22: $\% 22$ CSV $\% 22 \% 7 D$.

Bundesnetzagentur, 2019a. Bestätigung des Netzentwicklungsplans Strom für das Zieljahr 2030. Retrieved from https://www. netzentwicklungsplan.de/sites/default/files/paragraphs-files/ NEP2019-2030_Bestaetigung.pdf.

Bundesnetzagentur, 2019b. Bnetza-power-plant-list. Retrieved from https://www. bundesnetzagentur.de/DE/ Sachgebiete/ElektrizitaetundGas/Unternehmen_Institutionen/ Versorgungssicherheit/Erzeugungskapazitaeten/Kraftwerksliste/ kraftwerksliste-node.html.

Bundesregierung, 2019. Klimaschutzprogramm 2030 der Bundesregierung zur Umsetzung des Klimaschutzplans 2050. Retrieved from https://www. bundesregierung. de/resource/blob/975226/1679914/ e01d6bd855f09bf05cf7498e06d0a3ff/2019-10-09-klima-massnahmen-data. pdf?download=1.

Bødal, E.F., Mallapragada, D., Botterud, A., Korpås, M., 2020. Decarbonization synergies from joint planning of electricity and hydrogen production: A texas case study. International Journal of Hydrogen Energy 45, 32899-32915. URL: https://www. sciencedirect.com/ science/article/pii/s0360319920335679, doi:https://doi.org/10.1016/ j. ijhydene.2020.09.127.

Caglayan, D.G., Weber, N., Heinrichs, H.U., Linßen, J., Robinius, M., Kukla, P.A., Stolten, D., 2020. Technical potential of salt caverns for hydrogen storage in europe. International Journal of Hydrogen Energy 45, 6793-6805. URL: https: //www. sciencedirect. com/science/article/ pii/S0360319919347299, doi:https://doi.org/10.1016/j.ijhydene.2019. 12.161.

Deutsche Übertragungsnetzbetreiber, 2018. EEG-Anlagenstammdaten. Retrieved from https://www. netztransparenz. de/EEG/Anlagenstammdaten.

Dillinger, 2016. Produktion. URL: https://www.dillinger.de/d/de/ corporate/dillinger/produktion/.

Dillinger, 2019. Nachhaltige Stahlproduktion an der Saar. URL: https://www.dillinger.de/d/de/aktuelles/news/ 
nachhaltige-stahlproduktion-an-der-saar-88575. shtml.

Egerer, J., 2016. Open source Electricity Model for Germany (ELMODDE). DIW Data Documentation 83. German Institute for Economic Research (DIW). Berlin. URL: http://hdl . handle . net/10419/129782.

Emonts, B., Reuß, M., Stenzel, P., Welder, L., Knicker, F., Grube, T., Görner, K., Robinius, M., Stolten, D., 2019. Flexible sector coupling with hydrogen: A climate-friendly fuel supply for road transport. International Journal of Hydrogen Energy 44, 12918 - 12930. URL: http://www. sciencedirect.com/science/article/ pii/S0360319919312121, doi:https://doi.org/10.1016/j.ijhydene.2019. 03.183.

ENCON.Europe GmbH, 2018. Potentialatlas für Wasserstoff: Analyse des Marktpotentials für Wasserstoff, der mit erneuerbaren Strom hergestellt wird, im Raffineriesektor und im zukünftigen Mobilitätssektor. URL: https://www. dwv-info. de/wp-content/uploads/2018/04/ Potentialstudie- $f \% C 3 \% \mathrm{BCr}$-gr\%C3\%BCnen-Wasserstoff-in-Raffinerien pdf.

European Alternative Fuels Observatory, . European classification for vehicle category. Retrieved from https://www. eafo.eu/knowledge-center/ european-vehicle-categories. Accessed 25.03.2020.

European Commission, 2020. A hydrogen strategy for a climate-neutral europe. Retrieved from https://ec. europa.eu/energy/sites/ener/files/ hydrogen_strategy.pdf. Accessed 09.07.2020.

European Network of Transmission System Operators for Electricity, 2018. Transparency Platform. Retrieved from https://tyndp.entsoe. eu/maps-data.

European Network of Transmission System Operators for Electricity, 2021. Options for the design of European Electricity Markets in 2030. Retrieved from https://eepublicdownloads. entsoe.eu/clean-documents/ Publications/Market\%20Committee\%20publications/210331_Market_ design\%202030.pdf.

European parliament and European council, 2003. Regulation (ec) no $1059 / 2003$

FCH-JU, 2017. Development of business cases for fuel cells and hydrogen applications for regions and cities. Retrieved from https://www. fch.europa.eu/sites/default/files/171121_FCH2JU_ Application-Package_WG1_Heavy\%20duty\%20trucks\%20\%28ID\%202910560\% 29\%20\%28ID\%202911646\%29. pdf. Accessed 28.03.2020.

Federal Government of Germany, 2020. Die Nationale Wasserstoffstrategie. Retrieved from https://www.bmwi.de/Redaktion/DE/ Publikationen/Energie/die-nationale-wasserstoffstrategie.pdf?_blob=publicationfile\&v=12. Accessed 10.06.2020.

Fleiter, T., Schlomann, B., Eichhammer, W., 2013. Energieverbrauch und CO2-Emissionen industrieller Prozesstechnologien: Einsparpotenziale, Hemmnisse und Instrumente. Fraunhofer-Verlag. URL: https://www. isi.fraunhofer.de/content/dam/isi/dokumente/ccx/ 2013/Umweltforschungsplan_FKZ-370946130.pdf.

Fraunhofer-Institut, 2019. Eine Wasserstoff-Roadmap für Deutschland. Retrieved from https://www.ise. fraunhofer.de/content/ $\mathrm{dam} /$ ise/de/documents/publications/studies/2019-10_Fraunhofer_ Wasserstoff-Roadmap_fuer_Deutschland.pdf. Accessed 28.03.2020.

Fröhlich, T., Blömer, S., Münter, D., Brischke, L.A., 2019. CO2-Quellen für die PtX-Herstellung in Deutschland: Technologien, Umweltwirkung, Verfügbarkeit. URL: https://www. ifeu.de/wp-content/uploads/ifeu_ paper_03_2019_C02-Quellen-f\%C3\%BCr-PtX.pdf.

Golla, A., vom Scheidt, F., Röhrig, N., Staudt, P., Weinhardt, C., 2020. Vehicle scheduling and refuelling of hydrogen buses with on-site electrolysis. Jahrestagung der Gesellschaft für Informatik 2020 .

Grube, T., Stolten, D., 2018. The impact of drive cycles and auxiliary power on passenger car fuel economy. Energies 11. URL: https://www. mdpi. com/1996-1073/11/4/1010, doi:10.3390/en11041010.

Guerra, O.J., Eichman, J., Kurtz, J., Hodge, B.M., 2019. Cost competitiveness of electrolytic hydrogen. Joule 3, 2425 - 2443. URL: http://www. sciencedirect.com/science/article/pii/S2542435119303228, doi:https: //doi.org/10.1016/j. joule.2019.07.006.

H2 MOBILITY, 2019. Tankstellen. Retrieved from https://h2. live/en/ tankstellen.

Hebling, C., Ragwitz, M., Fleiter, T., Groos, U., Härle, D., Held, A., Jahn,
M., Müller, N., Pfeifer, T., Plötz, P., et al., 2019. Eine WasserstoffRoadmap für Deutschland. Fraunhofer-Institut für System-und Innovationsforschung ISI, Karlsruhe .

Hermann, H., Emele, L., Loreck, C., 2014. Prüfung der klimapolitischen Konsistenz und der Kosten von Methanisierungsstrategien. Technical Report. Öko-Institut e.V. URL: https://www. oeko. de/oekodoc/2005/ 2014-021-de.pdf.

HKM, 2020. Die Gesellschafter der HKM. URL: https://www.hkm.de/ unternehmen/gesellschafter/.

Hofbauer, H., Kaltschmitt, M., Keil, F., Neuling, U., Wagner, H., 2016. Vergasung in der Gasatmosphäre, in: Kaltschmitt, M., Hartmann, H., Hofbauer, H. (Eds.), Energie aus Biomasse: Grundlagen, Techniken und Verfahren. Springer, Berlin, Heidelberg, pp. 1059-1182. doi:10.1007/ 978-3-662-47438-9_13.

Hölling, M., Weng, M., Gellert, S., 2017. Bewertung der Herstellung von Eisenschwamm unter Verwendung von Wasserstoff. Stahl Und Eisen 137, 47-53.

Hydrogen Council, McKinsey \& Company, 2021. Hydrogen Insights. Retrieved from https://hydrogencouncil. com/wp-content/uploads/2021/02/ Hydrogen-Insights-2021-Report.pdf. Accessed 15.04.2021.

Hyundai, 2020. Erste Brennstoffzellen-Lkw Hyundai Xcient Fuel Cell kommen nach Europa. URL: https://www. hyundai. news/de/unternehmen/ erste-brennstoffzellen-lkw-hyundai-xcient-fuel-cell-kommen-nach-europa/.

IEA, 2015. Large-scale hydrogen delivery infrastructure. Retrieved from http://ieahydrogen .org/Activities/Task-28/Task-28-report_final_v2_ ECN_12_2_v3.aspx. Accessed 28.03.2020.

IEA, 2019. The Future of Hydrogen: Seizing today's opportunities. URL: https://webstore. iea.org/download/direct/2803?fileName= The_Future_of_Hydrogen. pdf.

IKTS, 2020. CO2-Emissionen bei der Stahlproduktion: Von 100 auf 5 Prozent! URL: https:// www.ikts. fraunhofer.de/de/presse/pressemitteilungen/ 29-9-2020-co2-emissionen-bei-der-stahlproduktion--von-100-auf-5html.

IVA, 2018. Wichtige Zahlen Düngemittel: Produktion, Markt und Landwirtschaft: Hersteller von Ammoniak, Stickstoff- und Phosphat-Düngemitteln (auf Rohphosphatbasis). URL: https: //www.iva.de/sites/default/files/benutzer/\%25uid/publikationen/ wichtige_zahlen_2017-2018.pdf.

Jendrischik, M., 2020. Total setzt in Leuna auf synthetisches Methanol. URL: https://www.cleanthinking.de/ synthetisches-methanol-total-sunfire-wasserstoff/.

Kießling, F., Nefzger, P., Kaintzyk, U., 2011. Freileitungen: Planung, Berechnung, Ausführung. Springer-Verlag.

Michalski, M., Altmann, M., Bünger, U., Weindorf, W., 2019. Wasserstoffstudie Nordrhein-Westfalen. Eine Expertiese für das Ministerium für Wirtschaft, Innovation, Digitalisierung und Energie des Landes Nordrhein-Westfalen, Düsseldorf .

MWV, 2020. Jahresbericht 2020. URL: https://www.mwv.de/ wp-content/uploads/2020/09/MWV_Mineraloelwirtschaftsverband-e. V. - Jahresbericht-2020-Webversion. pdf.

Nexant, I., Liquide, A., Laboratory, A.N., Venture, C.T., Institute, G.T., Laboratory, N.R.E., Laboratory, P.N.N., LLC, T., 2008. Wasserstoff: Bundesregierung schlägt Kriterien zur Umlagebefreiung vor. Retrieved from https://www. energate-messenger.de/news/210637/ wasserstoff-bundesregierung-schlaegt-kriterien-zur-umlagebefreiung-vor. Accessed 15.04.2021.

OpenStreetMap Contributors, 2020. Openstreetmap data for germany. Retrieved from https://download.geofabrik. de/europe/germany.html. Accessed 28.03.2020.

Peters, K., Thumann, R., 2016. Yara: Aus Dithmarschen-Wiki. URL: https://www. dithmarschen-wiki. de/Yara.

Prognos AG, 2020a. Energiewirtschaftliche Projektionen und Folgeabschätzungen 2030/2050. URL: https://www. bmwi.de/Redaktion/DE/ Publikationen/Wirtschaft/klimagutachten.pdf?__blob=publicationFile\& $v=8$.

Prognos AG, 2020b. Kosten und Transformationspfade für strombasierte Energieträger: Studie im Auf- 
trag des Bundesministeriums für Wirtschaft und Energie. URL: https://www.bmwi.de/Redaktion/DE/Downloads/Studien/ transformationspfade-fuer-strombasierte-energietraeger.pdf?_-blob=publicationfile.

Rechenberger, D., 2020. BASF SE Produktion Ammoniak: E-Mail.

Redenius, A., 2020a. SALCOS, WindH2, GrInHy - Wasserstoffprojekte bei der Salzgitter AG. URL: https://www. prozesswaerme.net/ fileadmin/Prozesswaerme/Dateien_Redaktion/Ausgewaehlte_Beitraege/ 13_sonderteil_salzgitter.pdf.

Redenius, A., 2020b. Vortrag auf der WerkstoffPlusAuto 2020: SALCOS - nachhaltige, flexible, CO2-arme Stahlproduktion.

Reuß, M., 2019. Techno-ökonomische Analyse alternativer Wasserstoffinfrastruktur. Ph.D. thesis. RWTH Aachen. doi:10.18154/RWTH-2019-07432.

Reuß, M., Grube, T., Robinius, M., Stolten, D., 2019. A hydrogen supply chain with spatial resolution: Comparative analysis of infrastructure technologies in germany. Applied Energy 247, 438-453. doi:https: //doi.org/10.1016/j. apenergy.2019.04.064.

Robinius, M., Otto, A., Syranidis, K., Ryberg, D.S., Heuser, P., Welder, L., Grube, T., Markewitz, P., Tietze, V., Stolten, D., 2017. Linking the power and transport sectors-part 2: Modelling a sector coupling scenario for germany. Energies 10. URL: https://www. mdpi.com/1996-1073/ 10/7/957, doi:10.3390/en10070957.

ROGESA, 2016. Daten und Fakten. URL: http://www. rogesa.de/rogesa/ produktion/daten/index.shtml.de.

Rose, P.K., Neumann, F., 2020a. Hydrogen refueling station networks for heavy-duty vehicles in future power systems. Transportation Research Part D: Transport and Environment 83, 102358. URL: http://www. sciencedirect.com/science/article/pii/S1361920920305459, doi:https: //doi.org/10.1016/j.trd.2020.102358.

Rose, P.K., Neumann, F., 2020b. Hydrogen refueling station networks for heavy-duty vehicles in future power systems. Transportation Research Part D: Transport and Environment 83. doi:https://doi .org/10.1016/j. trd.2020.102358.

Ruhnau, O., 2020. Market-based renewables: How flexible hydrogen electrolyzers stabilize wind and solar market values. Technical Report. Hertie School. Kiel, Hamburg. URL: http://hdl . handle. net/10419/227075.

Runge, P., Sölch, C., Albert, J., Wasserscheid, P., Zöttl, G., Grimm, V., 2019. Economic comparison of different electric fuels for energy scenarios in 2035. Applied Energy 233-234, 1078-1093. doi:https: //doi.org/10.1016/j.apenergy. 2018.10.023.

Runge, P., Sölch, C., Albert, J., Wasserscheid, P., Zöttl, G., Grimm, V., 2020. Economic comparison of electric fuels produced at excellent locations for renewable energies: A scenario for 2035. Working paper doi:http://dx. doi.org/10.2139/ssrn. 3623514.

vom Scheidt, F., Müller, C., Staudt, P., Weinhardt, C., 2020. The German electricity system in 2030: data on consumption, generation, and the grid. doi:10.5445/IR/1000124167.

Schmidt, O., Gambhir, A., Staffell, I., Hawkes, A., Nelson, J., Few, S., 2017. Future cost and performance of water electrolysis: An expert elicitation study. International Journal of Hydrogen Energy 42, 30470-30492. doi:https://doi.org/10.1016/j.ijhydene.2017.10.045.

Schweer, D., Scholz, G., Heisel, M., 2002. On-site-Versorgung von Erdölraffinerien mit technischen Gasen. Erdöl, Erdgas, Kohle 118, 115-120.

Shell, 2016. Shell nutzfahrzeug-studie diesel oder alternative antriebe - womit fahren $\mathrm{kw}$ und bus morgen? Retrieved from https:// www.shell.de/promos/media/shell-goods-vehicle-study/_jcr_content. stream/1466682556570/006b9c62dcca41b86d0adafc3ee2ad4fa14ef4d3/ shell-nutzfahrzeugstudie.pdf. Accessed 28.03.2020.

skw Piesteritz, 2015. Sicherheitsdatenblatt: Ammoniak. URL: https:// www. skwp.de/media-center/broschueren/reach/.

Stagge, M., 2020. Wasserstoffbedarf thyssenkrupp 2030: E-Mail.

Staudt, P., 2019. Transmission Congestion Management in Electricity Grids-Designing Markets and Mechanisms. Ph.D. thesis. KITBibliothek.

Staudt, P., Oren, S., 2020. A merchant transmission approach for uniformprice electricity markets, in: Proceedings of the 53rd Hawaii International Conference on System Sciences, pp. 1-10.

Staudt, P., Rausch, B., Gärttner, J., Weinhardt, C., 2019. Predicting trans- mission line congestion in energy systems with a high share of renewables, in: 2019 IEEE Milan PowerTech, pp. 1-6. doi:10.1109/PTC. 2019. 8810527.

Staudt, P., Wegner, F., Garttner, J., Weinhardt, C., 2017. Analysis of redispatch and transmission capacity pricing on a local electricity market setup, in: 2017 14th International Conference on the European Energy Market (EEM), pp. 1-6.

swb, 2020. Nachhaltigkeit: Wasserstoff: Mit grünem Stahl Emissionen reduzieren. URL: https://www.swb.de/ueber-swb/unternehmen/ nachhaltigkeit/wasserstoff/elektrolyseur.

Thoma, H.J., 2020. Methanol Produktionskapazität: E-Mail.

thyssenkrupp, 2019. Wasserstoff statt Kohle. thyssenkrupp Steel startet wegweisendes Projekt für eine klimafreundliche Stahlproduktion am Standort Duisburg. URL: https://www. thyssenkrupp-steel.com/de/ newsroom/pressemitteilungen/wasserstoff-statt-kohle.html.

thyssenkrupp, 2020a. Die Klimastrategie von thyssenkrupp Steel zur nachhaltigen Stahlproduktion. URL: https://www. thyssenkrupp-steel.com/ de/unternehmen/nachhaltigkeit/klimastrategie/.

thyssenkrupp, 2020b. Grüner Wasserstoff für die Stahlproduktion: RWE und thyssenkrupp planen Zusammenarbeit. URL: https: //www. thyssenkrupp-steel.com/media/content_1/presse/dokumente/ 2020_1/juni_2/20200610_pm_thyssenkrupp_steel_loi_rwe_pre-final.pdf. VCI, 2020. Chemiewirtschaft in Zahlen 2020. URL: https://www.vci. de/vci/downloads-vci/publikation/chemiewirtschaft-in-zahlen-print. pdf.

Victoria, M., Zhu, K., Brown, T., Andresen, G.B., Greiner, M., 2019. The role of storage technologies throughout the decarbonisation of the sectorcoupled european energy system. Energy Conversion and Management 201, 111977. URL: https://www.sciencedirect.com/science/article/ pii/S0196890419309835, doi:https://doi.org/10.1016/j.enconman.2019. 111977.

vom Scheidt, F., Qu, J., Staudt, P., Mallapragada, D., Weinhardt, C., 2021. The effects of electricity tariffs on cost-minimal hydrogen supply chains and their impact on electricity prices and redispatch costs. Proceedings of the 54th Hawaii International Conference on System Sciences .

Warscheid, L., 2020a. Fahrplan der Saar-Stahlkocher zum grünen Stahl. Saarbruecker Zeitung 2020. URL: https: //www. saarbruecker-zeitung. de/saarland/saar-wirtschaft/ stufenplan-zu-gruenem-stahl-aus-dem-saarland-bis-2050_ aid-53012835.

Warscheid, L., 2020b. In Dillingen wird jetzt mit Wasserstoff gekocht. Saarbruecker Zeitung 2020. URL: https: //www. saarbruecker-zeitung. de/saarland/saar-wirtschaft/ neue-anlage-von-rogesa-saarstahl-dillinger-nutzt-wasserstoff_ aid-52906817?utm_source=mail\&utm_medium=referral\&utm_campaign= share\#successLogin.

Weger, L.B., Leitão, J., Lawrence, M.G., 2020. Expected impacts on greenhouse gas and air pollutant emissions due to a possible transition towards a hydrogen economy in german road transport. International Journal of Hydrogen Energy URL: http: //www. sciencedirect. com/ science/article/pii/S0360319920341847, doi:https://doi.org/10.1016/ j.ijhydene.2020.11.014.

Wilms, S., Schäfer-Stradowsky, S., Jahnke, P., 2018. Heutige Einsatzgebiete für Power Fuels-Factsheets zur Anwendung von klimafreundlich erzeugten synthetischen Energieträgern. URL: https://www. dena.de/fileadmin/dena/Publikationen/PDFs/2019/181123_ dena_PtX-Factsheets.pdf.

WV Stahl, 2020. Statistisches Jahrbuch der Stahlindustrie 2019/2020.

Xiong, B., Predel, J., Crespo del Granado, P., Egging-Bratseth, R., 2021. Spatial flexibility in redispatch: Supporting low carbon energy systems with power-to-gas. Applied Energy 283, 116201. URL: https://www. sciencedirect.com/science/article/pii/S0306261920315981, doi:https: //doi.org/10.1016/j. apenergy. 2020.116201.

Yilmaz, C., 2018. Maßnahmen zur Dekarbonisierung des Hochofenprozesses durch Einsatz von Wasserstoff. Cuvillier Verlag.

Zhang, C., Greenblatt, J.B., Wei, M., Eichman, J., Saxena, S., Muratori, M., Guerra, O.J., 2020. Flexible grid-based electrolysis hydrogen production for fuel cell vehicles reduces costs and greenhouse gas emissions. 
Applied Energy 278, 115651. URL: https://www. sciencedirect.com/ science/article/pii/s0306261920311491, doi:https://doi.org/10.1016/ j. apenergy. 2020.115651.

\section{A. Appendix A: Hydrogen demand data}

Steel To identify all steel plants with potential for hydrogen use in 2030, we use the statistical report of the steel industry (WV Stahl, 2020). Looking at future hydrogen demand, only those $70 \%$ of steel producers who manufacture via the blast furnace route are relevant, as large quantities of $\mathrm{CO}_{2}$ are emitted here and can be avoided by switching to the direct reduction route. In addition, the ArcelorMittal plant in Hamburg is included, as it already uses a direct reduction approach (Hölling et al., 2017). Table 4 lists the eight identified steel production sites.

The production volumes and relative shares of primary and secondary steel in Germany have been approximately constant since 2012 (WV Stahl, 2020). Therefore, and in line with Hebling et al. (2019), we use past production volume and distribution as 2030 estimates. In particular, we use 2017 values, as only those are available in (WV Stahl, 2020). Table 4 shows the crude steel quantities produced in 2017 for each identified site with potential hydrogen demand.

However, it can be assumed that not all steel producers will switch to direct reduction by 2030 , due to various reasons. For instance, the switch is associated with high investment costs, is technically demanding (IKTS, 2020), and comes with new uncertainties like future hydrogen costs (Agora Energiewende and Wuppertal Institut, 2019). Correspondingly, steel producers are planning individual solutions for medium-term $\mathrm{CO}_{2}$ emission reduction to achieve reduction goals. Therefore, all relevant plants must be analyzed individually.

ArcelorMittal Hamburg has been operating a direct reduction plant since the mid-1970s (Hölling et al., 2017). The reduction gas used today consists of about $60 \%$ hydrogen (ArcelorMittal, 2017). By 2030, steel production is planned to be completely $\mathrm{CO}_{2}$-neutral (ArcelorMittal, 2020a). Accordingly, we assume that there will be a complete switch to the direct reduction route with $100 \%$ hydrogen input by 2030. For the direct reduction route, we assume the specific hydrogen demand factor $80 \mathrm{~kg}_{\mathrm{H}_{2}} / \mathrm{t}_{\text {steel }}$, based on Michalski et al. (2019). The hydrogen demand of ArcelorMittal Hamburg for the year 2030 is estimated with equation 30 .

$$
\begin{array}{r}
H D=\text { Output }_{t_{\text {Steel }}} * \text { specific Demand Factor } \\
* 33.33 \mathrm{kWh} h_{\mathrm{H}_{2}} / \mathrm{kg}_{\mathrm{H}_{2}}
\end{array}
$$

ArcelorMittal Eisenhüttenstadt and ArcelorMittal Duisburg have not publicly announced any plans to use hydrogen until 2030, but it has been indicated that long-term adoption of hydrogen for the former plant will depend on the results of current pilot projects of the ArcelorMittal group (Antenne Brandenburg, 2020; ArcelorMittal, 2020b). Therefore, we assume that these plants do not have any hydrogen demand in 2030 .
ArcelorMittal Bremen is focusing on the use of hydrogen via the blast furnace route to achieve the medium-term goals. However, the company already plans to construct an electrolyser on-site (swb, 2020) that will be sufficient to fully meet the hydrogen demand in 2030. Thus, the plant does not have any net demand for hydrogen.

ROGESA, a subsidiary of Dillinger and Saarstahl, produces pig iron, which is supplied to Dillinger and Saarstahl for the subsequent crude steel production (Dillinger, 2016). Therefore, Dillinger and Saarstahl are considered collectively for further calculations. ROGESA operates two blast furnaces and plans to optimise both by blowing in hydrogen as a reducing agent in order to achieve a reduction in $\mathrm{CO}_{2}$ emissions (Dillinger, 2019). According to a step-by-step plan of the Saarland-based steel industry, both blast furnaces are to remain in operation until 2031 (Warscheid, 2020a). In addition, an electric furnace and a direct reduction plant are to be built, which will initially only use natural gas to produce directly reduced iron from iron ore (Warscheid, 2020a). Therefore, we assume that by 2030, both blast furnaces will use the maximum amount of hydrogen. Both blast furnaces are technically able to use a maximum of approximately 3,700 $k g_{\mathrm{H}_{2}} / h$ (Warscheid, 2020b; ROGESA, 2016). Thus, the hydrogen demand of ROGESA (Dillinger and Saarstahl) for the year 2030 is estimated to be $2.1606 T W h_{H_{2}}$, based on equation 31.5

$$
\begin{array}{rl}
H D=2 & * 3700 \mathrm{~kg}_{\mathrm{H}_{2}} / \mathrm{h} * 8760 h \\
& * 33.33 \mathrm{~kW} h_{\mathrm{H}_{2}} / \mathrm{kg}_{\mathrm{H}_{2}}
\end{array}
$$

Hüttenwerke Krupp Mannesmann (HKM) is owned 50 $\%$ by Thyssenkrupp Steel Europe AG, $30 \%$ by Salzgitter Mannesmann $\mathrm{GmbH}$ and $20 \%$ by the French company Vallourec Tubes S.A.S (HKM, 2020). Regarding the use of hydrogen in production, no press reports were found that were published by HKM. Consequently, it is assumed that due to the structure of the company, no hydrogen will be used until 2030, as the shareholders might primarily concentrate on their own production facilities and their optimisation.

Salzgitter is pursuing a gradual conversion to hydrogenbased steel production via the direct reduction/electric arc furnace route. In the first stage of expansion, a direct reduction plant and an electric arc furnace will be built (Redenius, 2020a). This expansion stage will lead to a hydrogen use of $81,332 \mathrm{Nm}^{3} / \mathrm{h}$ and a specific hydrogen demand factor of $12.27 \mathrm{~kg}_{\mathrm{H}_{2}} / \mathrm{t}_{\text {steel }}$ (Redenius, 2020b) for the overall plant output. Thus, the hydrogen demand for 2030 can be calculated with equation 30 .

Thyssenkrupp plans to replace two blast furnaces with two direct reduction plants, and to optimize one blast furnace by blowing in hydrogen until 2030 (thyssenkrupp, 2020a). Current estimations indicate that around 200,000 tons of hydrogen per year will be needed from 2030 (Stagge, 2020). A share of this will be supplied through a long-term contract

\footnotetext{
${ }^{5}$ To validate the results, we also estimate the demand with equation 30 , which returns $2.0668 T W h_{H_{2}}$ and thus confirms the calculations. For all further calculations, we use $2.1606 T W h_{H_{2}}$ as demand for the Dillinger and Saarstahl steel plants.
} 
with RWE, from a $100 \mathrm{MW}$ electrolyzer capable of supplying 1.7 tons of hydrogen per hour (thyssenkrupp, 2020b). This supply is deducted from the total demand in order to calculate the hydrogen net demand for 2030 as shown in equation 32 .

$$
\begin{array}{r}
H D=\left(200,000,000 k_{H_{2}}-1,700 k g_{H_{2}} / h\right. \\
* 8,760 h) * 33.33 k W h_{H_{2}} / k_{H_{2}}
\end{array}
$$

Ammonia The hydrogen demand from the German ammonia industry can be estimated as follows. The ideal specific hydrogen demand for ammonia synthesis is 3 moles of $\mathrm{H}_{2}$ for 2 moles of $\mathrm{NH}_{3}$ (Hermann et al., 2014), or $177.55 \mathrm{~kg}_{\mathrm{H} 2}$ per ton of ammonia.

We acquire a list of all ammonia producers in Germany from the Industrial Association Agrar (IVA, 2018). The production volumes of ammonia in Germany have been approximately constant since 2012 (VCI, 2020). While, to the best of our knowledge, no information on site-specific current ammonia production is publicly available, we identify sitespecific production capacities based on skw Piesteritz (2015); Peters and Thumann (2016); Bezirksregierung Köln (2017); Rechenberger (2020). The sum of these capacities $(2,955,000$ t/a) is somewhat higher than the current total ammonia production $(2,415,327$ in 2019). However, global ammonia demand is assumed to increase by 2030 (Hebling et al., 2019; IEA, 2019). Therefore, in the following, the production capacities are assumed as basis for the site-specific hydrogen demand estimation.

Regarding self-supply, no information on large-scale electrolysers at the identified ammonia plants was found. While BASF (2020) is building its own electrolysis plant for research purposes, no details are available about any large scale operation. Correspondingly, the total demand is assumed to be equal to the net demand. With the assumptions made above, the site-specific demand can be estimated with equation 33 .

$$
\begin{array}{r}
H D=t_{\text {Ammonia }} \\
* 177.55 \mathrm{~kg} / t_{\text {Ammonia }} \\
* 33.33 \mathrm{kWh} h_{\mathrm{H}_{2}} / \mathrm{kg}_{\mathrm{H}_{2}}
\end{array}
$$

Methanol The specific hydrogen demand is estimated as 2 moles of $\mathrm{H}_{2}$ for 1 mole of $\mathrm{CH}_{3} \mathrm{OH}$ (Hofbauer et al., 2016), or $188.73 \mathrm{~kg}_{\mathrm{H} 2}$ per ton of methanol. This is consistent with the assumptions of Bazzanella and Ausfelder (2017) and Michalski et al. (2019). Currently, there are five relevant methanol plants in Germany (Fröhlich et al., 2019). However, one of them has terminated production and is being liquidated (Thoma, 2020), and therefore is disregarded for 2030.

In the next step, production capacities of the individual plants are identified (Fleiter et al., 2013; Jendrischik, 2020; BP, 2019). The sum of current production of $1,398,146 \mathrm{t} / \mathrm{a}$ (VCI, 2020) is lower than the total production capacity of $1,865,000 \mathrm{t} / \mathrm{a}$. However, production has been rising in recent years, and global methanol demand is assumed to increase by 2030 (Hebling et al., 2019; IEA, 2019). Correspondingly, as with the hydrogen estimate for ammonia, the production capacity is used as basis for further calculations.
Regarding self-supply, there are smaller electrolyzers for research purposes (Jendrischik, 2020; BASF, 2020), but no information on large-scale electrolysers at the identified ammonia plants was found. Correspondingly, the total demand is assumed to be equal to the net demand. With the assumptions made above, the site-specific demand can be estimated with equation 34 .

$$
\begin{array}{r}
H D=t_{\text {Methanol }} \\
* 188.73 \mathrm{~kg} / t_{\text {Methanol }} \\
* 33.33 \mathrm{kWh} h_{\mathrm{H}_{2}} / \mathrm{kg}_{\mathrm{H}_{2}}
\end{array}
$$

Refineries We use the list of all refineries and their output capacities from the German Petroleum Industry Association (MWV, 2020). Mineral oil consumption will decrease by varying degrees by 2030 , depending on assumptions about the demand for liquid fuels (Michalski et al., 2019). Correspondingly, the current production volume of $87,013,000$ tons is distributed across the sites in proportion to their processing capacity. Then, derived from the results of Prognos AG (2020a), the assumption is made that the demand for mineral oil will decrease by about $20 \%$ until 2030 .

The specific hydrogen net demand is assumed to be approximately $100 \mathrm{~m}^{3} \mathrm{H} 2$ per ton crude oil, based on Schweer et al. (2002). Thus, the site-specific hydrogen demand for refineries can be estimated with equation 35 .

$$
\begin{aligned}
H D & =t_{\text {Oil }, p q, 2030} * 100 m^{3} / t_{O i l, p q, 2030} \\
& * 0,0841 * k W h_{\mathrm{H}_{2}} / \mathrm{kg}_{\mathrm{H}_{2}} * 22 \%
\end{aligned}
$$

\section{B. Appendix B: Conversion factors}

\section{Table 11}

Numeric values and conversion factors for $\mathrm{H}_{2}$

\begin{tabular}{ll}
\hline Lower heating value of hydrogen & $33.33 \mathrm{kWh} / \mathrm{kg}$ \\
Conversion factor $\mathrm{kg}$ in $\mathrm{m}^{3}$ & 11.89 \\
Conversion factor $\mathrm{m}^{3}$ in $\mathrm{kg}$ & 0.0841 \\
\hline
\end{tabular}

